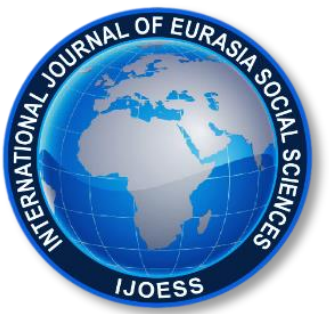

International Journal of Eurasia Social Sciences

Vol: 11, Issue: 40, pp. (530-571).

Article Type: Research Article

Received: 22.11.2019

Accepted: 05.05.2020

Published: 07.06.2020

\title{
HOW WERE THE LAW ON UNITY OF EDUCATION AND LETTER REVOLUTION PROCESSED IN THE HUMOR MAGAZINES OF THE PERIOD?
}

\author{
Mehmet Akif SUBAŞI \\ Master Student, Istanbul Sabahattin Zaim University, Turkey, masubasi34@gmail.com \\ ORCID: 0000-0002-7659-5317 \\ Beytullah KAYA \\ Assoc. Prof., istanbul Sabahattin Zaim University, Turkey, beytullah.kaya@izu.edu.tr \\ ORCID: 0000-0002-9060-1664
}

\begin{abstract}
The Republic of Turkey has wanted to move forward with the legacy of the Ottoman State have taken innovation and reform movements. The establishment of a new state caused a period of joy in the public and visual media due to the difficulties experienced during the National Struggle period. Innovation and reform movements in the period of this joy are fundamentally changing the social structure and institutions that have been going on for centuries. There have been many revolutions that have influenced education, law, economic and everyday life. Considering the low literacy rate, it is thought that the public is seriously affected by the print media. The effect of Tawhid-i Tedrisat Law (Law on Unity of Education) and Letter Revolution on humor journals, which is important among these changes, was investigated. In this respect, it is seen that there was no significant criticism against the government of the period based on the publications between 1924 1928 in Zümrüd-ü Anka and Akbaba humor magazines, which were examined within the framework of the Law of Tevhid-i Tedrisat and Letter Revolution. It is understood from the studies that illustrators, who made publications, support these reforms, especially in humor magazines and newspaper publications directed towards innovation and reform movements.
\end{abstract}

Keywords: Zümrüd-ü Anka Magazine, Akbaba Magazine, The Law on Unity of Education, Letter Revolution. 


\section{INTRODUCTION}

The narrative of history is based on three main lines: written, oral and visual. Written and oral history expressions are complemented by visual materials (Sakin, 2011: 11). People have used different methods to express their feelings and thoughts since ancient times. It is possible to reach visual drawings on stone, relief, sculpture and similar stone in ancient Egypt, Rome, Hittite, Greek and other eastern cultures (Kayış, 2004: 4). Printed visual materials, which started to be used in the 19th century, became one of the most important news sources that attracted the attention of the societies with the progress of the age.

The use of caricatures in newspapers and magazines in the Ottoman State emerged with the establishment of printing houses as in western countries. In the periods when the use of photography has not yet begun, the illustrators, who we call today cartoonists, tried to tell the public by adding humor to the events of the period (Arık, 2002: 238). Humor cartoons written by hand skill have gained a certain reputation among the public due to the scarcity of literate people. People could learn about particular events in countries as well as current issues through humor by following the publication of this kind. According to the flexibility of the period conditions, humor publications began to be published by expressing criticism and ridicule in political and social events (Arik, 2002: 239). The political cartoons drawn with humor aim to make the reader think while making them laugh.

In the Ottoman State, cartoons were first used during the Tanzimat Period. Although humor press continued to publish until the announcement of Kanuni Esasi, after a while there was a decrease in publications. However, after the declaration of the Second Constitutional Monarchy, there was a significant increase in the number of humor newspapers and humor magazines (Hünerli, 1993: 28). The Ottoman State, which signed the Armistice of Mondros on October 30,1918, accepted that it was defeated in World War I and its lands began to be occupied. As a matter of fact, the cartoons used in this period and the publications in humor magazines were mostly about the Independence War against the occupation states and the Ankara Government, which made efforts for the National Struggle in Anatolia. During this period, newspapers were using their works like a soldier, and printed images and publications were used as weapons. Although there were publications in the press of the occupation states, the humor press had an important responsibility in the public expression of the national struggle (Kaya \& Acarli, 2018: 132).

With the success of the War of Independence and the liberation of the land from the enemy occupation, all of the press organizations published publications praising success and emphasizing nationalist ideas. During this period, there were 21 journals published as humor magazines. The main magazines are: “Karagöz (1908-1950), Diken (1918-1919), Güleryüz (1921-1923), Aydede (1922), Ayine (1921-1923), Akbaba (1922-1977), Zümrüdü Anka (1923-1925), Kelebek (1923-1924)" (Çeviker, 2010: 21). On 23 April 1920 with success in the War of Independence, after the opening of the Grand National Assembly (Günal, 2008: 230) in Ankara government is terminating the National Struggle (Baykara, 2011: 164). After the signing of the Lausanne Peace Treaty, a new era started with the occupation forces left Istanbul and other Anatolian lands. 
With the proclamation of the Republic on 29 October 1923, a new era began for the cartoon and humor press. Especially the innovation decisions taken during this period have been reflected in the cartoons and visual publications in the printed media. November 3,1928, with the abandonment of the Arabic alphabet and the use of Latin letters instead of the revolution of letters, a new era began for the life of the printed press (Öngören, 1998: 73). The most important feature of the period between 1923 and 1928 for the press and publication life is that the Ottoman language was written in Arabic letters. In addition, another feature of this period, causing public happiness and free period for press with the success of the National Struggle (Öngören, 1998: 76).

During the Republican period, a significant portion of the newspapers began to feature caricatures and drawings on their pages. Early Republican caricature publication should be divided into two; the first period is the period from 29 October 1923 until the declaration of the Republic to 3 November 1928. The second term is accepted as the transition from the Letter Revolution to multi-party life with the elections of 21 July 1946 . This period is generally accepted as the period in which cartoonists use the art of caricature comfortably and put their narrative into drawing (Çeviker, 2010: 22).

\section{PURPOSE}

This study, with the success of the liberation struggle in this period is considered the founding stage of the Republic of Turkey, aimed to investigate and examine the perspectives of humor and caricature magazines on the Law on Unity of Education and the Letter Revolution. In this framework, the following sub-problems were sought:

1. How are the characteristics of the period reflected in the humor press?

2. How were the Law of Tawhid-i Tedrisat and the Letter Revolution handled in the early periods of the Republic in the humor publications?

3. Were there any political biases in the journals of Akbaba and Zümrüd-ü Anka to be examined in the context of the Law of Tawhid-i Tedrisat and the Letter Revolution?

\section{METHOD}

"Case study method" was used in this study. Case study which is a qualitative research method which is used for in-depth research and description of one or more events, phenomena or a limited system (Büyüköztürk et al., 2018: 60; Karataş, 2015: 63). Case study is a systematic study design aiming at collecting data, planning the collected data, reaching the findings and interpreting these findings (Berrak, 2012: 3). In this study, considering the conditions of the period, 'Descriptive Analysis Method', which is one of the qualitative data analysis methods, was used because of the evaluation of the publications of some humor journals on the Law of Tevhid-i Tedrisat and Letter Revolution and examining the relationship between events. The aim of the descriptive analysis is to edit and interpret the data and present it to the reader. In this direction, the data obtained were arranged and 
described systematically and clearly. The data obtained were trying to be described and interpreted. Finally, the results were obtained by examining the cause-effect relationship (Yıldırım \& Şimşek, 2005: 224).

In this study, it was aimed to determine how visual publications of a period perceive the developments of the period. In this context, it is thought that the descriptive analysis method, which is one of the case study methods, is appropriate for the structure of this study. The documents and instruments required for the study were obtained from Beyazit State Library, Farabi digital library of the Research Centre for Islamic History, Art and Culture (IRCICA) and the newspapers and magazines known as Hakkı Tarık Us Collection and transferred to digital media.

\section{FINDING}

\section{MAJOR HUMOR-CARTOON MAGAZINES AND NEWSPAPERS OF THE PERIOD}

\section{a)Akbaba Magazine (1922-1977)}

At the time of the War of Independence, Aydede and Güleryüz magazines continued to publish in terms of Turkish cartoon and humor magazines. While Sedat Simavi, the founder of Güleryüz magazine, has been making publications that support the Ankara Government, Refik Halid Karay had been supporting the Istanbul Government in Aydede (Tonga, 2008: 666). After the successful completion of the War of Independence, Refik Halid Karay escaped from the country and with the closure of Aydede magazine, "Akbaba" magazine was founded by Yusuf Ziya Ortaç (Cantek \& Gönenç, 2017: 11). Akbaba is the longest-running magazine among Turkish cartoon and humor magazines. In 55 years of publication, the magazine has been closed three times(Öğdü, 2011: 31). Almost all the publication staff of Aydede magazine met at Akbaba. The main Artists are: "Münif Fehim, Ramiz Gökçe, İsmail Hakkı, Hasan Rahim (Us), İhap Hulusi (Görey), Ratip Tahir Burak, Cemal Nadir Güler" (Sakin, 2011: 71).

\section{b) Zümrüd-ü Anka Humor Magazine (1923-1925)}

Zümrüd-ü Anka Humor magazine, which was founded on January 11, 1923, ceased its activities on April 23, 1925 shortly after the establishment of the Republic(Yılmaz N. F., 2017: 77). The fact that it was the first humor magazine established during the Republican period made this magazine important. Some of the authors of the journal, which is published twice a week, Monday and Thursday, are; "Orhan Seyfi (Orhon), Yusuf Ziya (Ortaç), Peyami Safa, Selami İzzet (Sedes), A. Lütfü”. Some of the most important cartoonists are; Ramiz (Gökçe), Zeki Cemal (Bakiçelebioğlu), İsmail Hakkı, Ahmet Münif (Fehim), Ratip Tahir (Burak), Cevat Şakir (Kabaağaçlı), Hasan Fehmi (Us), Ahmet Rıfkı, Cemal Nadir(Güler)”' (Yılmaz H. , 2016: 66). This magazine, owned by Semih Lütfi Erciyas, criticized the cultural and social change of the period by focusing on innovation and reform movements in the early years of the Republic. However, Zümrüd-ü Anka magazine started its publication life 2 years and 3 months later with the number 224 ended the publication soon after the announcement of Takrir-i Sükûn Law (Yılmaz N. F., 2017: 77). 


\section{TEVHID-i TEDRISAT LAW}

The establishment of the Republic of Turkey, especially in the first ten-year period, while serious social and structural changes on the basic dynamics of the legacy inherited from the Ottoman State, could not be expected not to reform in education (Zengin, 2002: 81). With the end up of the National Struggle Period, within the scope of renewal movement began in the Republic of Turkey, the idea of the regeneration of the Ottoman alphabet produced from Arabic alphabet was discussed in Izmir Economy Congress at the request of Ghazi Mustafa Kemal. Four days after this congress “Maarif Misakı" (also known as “Education Commemoration”) (Ertan vd., 2018: 188) was declared with regard to the reconsideration of education and training on March 8, 1923.

After the proclamation of the Republic, the madrasah education, which has been going on since the Ottoman State period, was thought to have little effect on the literacy of the people and there were dichotomies in the education system. In addition, due to non-supervision of foreign schools, all institutions engaged in educational activities were asked to gather under one roof (Ertan vd., 2018: 188). Negotiations were held at the opening of the second session of the Grand National Assembly (Arl, 2002: 185) on 1 March 1924 in order to ensure the educational structure appropriate for the Republican period (Kocatürk, 2000: 409). In these meetings, issues were discussed except for the Law on Unification of Education. In the opening speech of Ghazi Mustafa Kemal at the session on March 1, he focused on three main topics and stated them in his book Nutuk as follows:

1. "The nation demands that now, in the future, for ever and unconditionally the Republic shall be protected frolm every attack. The wish of the naiton can be expressed through the fact that the Republic will be founded a moment earlier and completely on the wholr of positive principles which have been put to the test."

2. "We declare that it is necessary without loss of time to apply the principle of unity of instruction and education which has been decided by the vote of nation."

3. "We also recognise that it is indispensable in order to secure the revival of the Islamic Faith, to disengage it from the condition of being a political instrument, which it has been for centuries through habit"(Atatürk, 2009: 574).

A day later, at the group meeting of the People's Party on March 2, 1924, these headings proposed by Ghazi Mustafa Kemal were discussed and presented to the Parliament on 3 March 1924 (ArI, 2002: 187) by the party deputies. The three proposals submitted to the Presidency of the Assembly are as follows:

1. "Draft of the law of Sheikh Safvet Effendi and fifty of his colleagues concerning the abolition of the Caliphate and the expıulsion of the Ottoman dynasty from Turkish territory."

2. "Draft of the law of Halil Hulki Effendi, deputy for Seerd, and fifty of his colleagues concerning the suppression of the Ministry for Religious Affairs, of the Evkaf and Ministry of the General Staff." 
3. "Motion of Vassif Bey, deputy for Saruchan, and fifty of his colleagues concerning the unification of instruction" (Atatürk, 2009: 574).

Although some deputies objected to these articles, the Law on Unification of Education was also adopted and all educational institutions in the country were connected to the Ministry of Education (Ertan vd., 2018: 188). With the Law on the Organization of Education (Kocatürk, 2000: 452) adopted on 22 March 1926 in the Assembly, additions were made to the Law on Unification of Education and the opening of schools without the permission of the state was prevented (Ertan et al., 2018: 188).

\section{LETTER REVOLUTION}

Before accepting Islam, the Turks began to use the Arabic alphabet while using the Göktürk and Uighur alphabets (Avcl, 2013: 44). The Arabic letters, which continued to be used during the Ottoman State, brought about discussions with the proclamation of the Republic. In some sources, it is stated that the idea of innovation about Letter Revolution dates back to Tanzimat Edict (Acar, 2012: 22). Although it is not certain stated in some publications that Mazhar Müfit Kansu, one of his companions of Ghazi Mustafa Kemal, right after the end of the First World War during the Erzurum Congress before the War of Independence, made note (Ertan et al., 2018: 189) of the Latin Letters topic.

Ghazi Mustafa Kemal expressed the issue of Letter Revolution in the innovation movements that he started with the end of the War of Independence and wondered about the reaction of the society and followed the discussions closely (Inan, 2018: 183). In the Republican period, the first studies on Letter Revolution were based on the İzmir Economic Congress. There were harsh debates in the meetings held at this congress, but the request for the transition to Latin letters was not accepted when the president of the congress Kazim Karabekir Pasha (Turan, 2018: 388) refused. On 24 February 1924, İzmir deputy Sukru Saracoglu proposed the abolition of the Arabic alphabet but was not accepted again as a result of the debates in the parliament. Mustafa Kemal did not support the removal of this issue in this period, considering that it was not accepted by the public (Turan, 2018: 388).

After the initial attempts for the Letter Revolution, the first step was taken on 20 May 1928 with the introduction of international figures (Kocatürk, 2000: 478). Only three days after this date, upon the instruction of President Mustafa Kemal, it was decided to establish a Language Commission (Turan, 2018: 388) within the Ministry of National Education. The President also participated in the work of this three-month commission (Inan, 2018 : 183).

At the end of the studies, the President of Turkey Mustafa Kemal made a speech in accordance with the significance of the adoption of the new Latin alphabet in the opening of the Grand National Assembly on November 1, 1928 (Ertan et al., 2018: 190). Following this speech, the draft law prepared by the Language Commission was accepted. On 3 November 1928, the law entered into force and was published in the official 
newspaper (İnan, 2018: 185). Thus, the Arabic letters used by the Turks since the adoption of the Islamic religion were left and passed to the Latin letters.

SOME CARICATURES RELATED TO THE LAW OF TEVHID-I TEDRISAT AND THE LETTER REVOLUTION

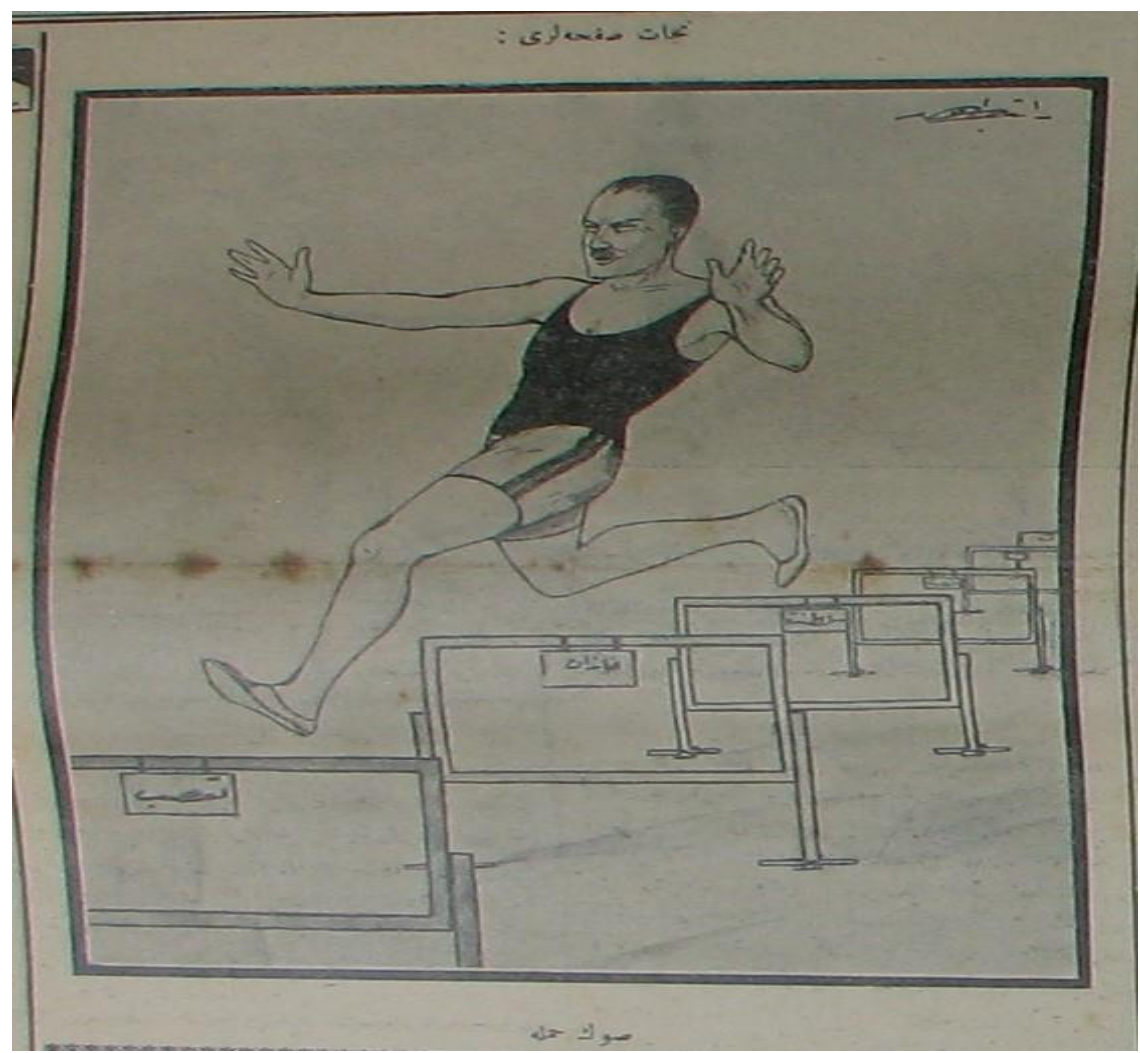

Caricature-1 (Tahir, 1924)

\section{Translation of Caricature}

Cover Letter: Necat(liberation) time.

Respectively from the fourth obstacle: Reign, Dynasty and Taassub (bigotry).

Subtitle: End Game. 


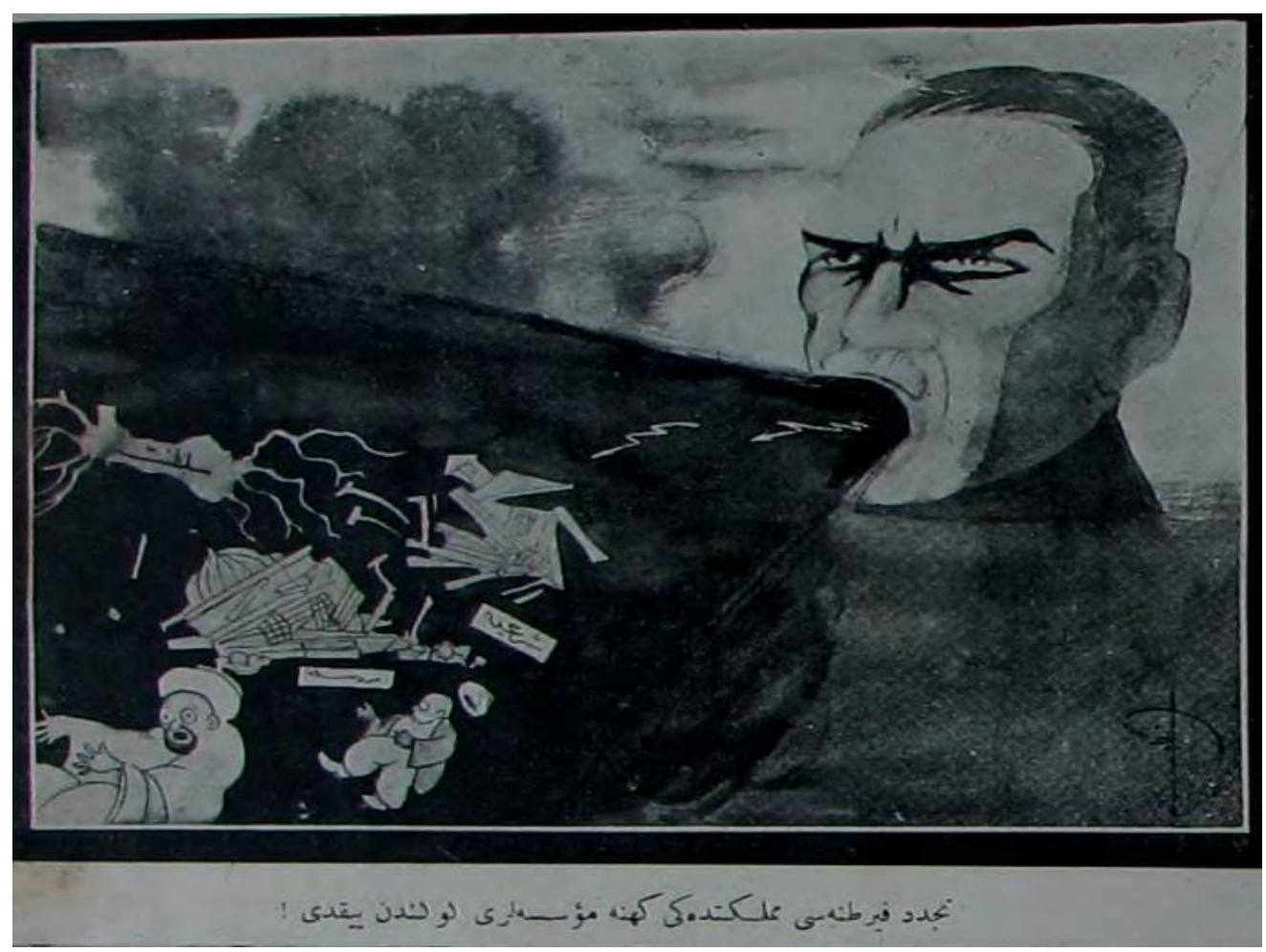

Caricature-2 (Gökçe, 1924)

\section{Translation of Caricature}

Subtitle: The storm of Tecdidi (regeneration) destroyed the outdated institutions in the country.

\section{About Caricature 1 and 2}

Ratib Tahir, the cartoonist of Caricature 1, drew some of the innovations made after the founding of the Republic as an obstacle, and pointed out that Mustafa Kemal would successfully complete the race after each jump. The last move is taassub that means bigotry. In Caricature 2, the illustrator painted a storm from Mustafa Kemal's mouth and drew innovation movements. Inside the storm, there are ruined madrasah and robes with turbaned robes. In the storm, shari'ah, sultanate and madrasah were written in Ottoman Turkish. It was pictured that the storm pulled these institutions like a hose thanks to Ghazi Mustafa Kemal. Articles submitted and adopted to the Assembly on 3 March 1924; The exile of the Ottoman dynasty and the abolition of the caliphate, removal of Power of Attorney and Ministry of Evil and Evkaf and gathering education under one roof. The two caricatures published after these laws do not contain any criticism and it is seen that the innovations and government are supported. 


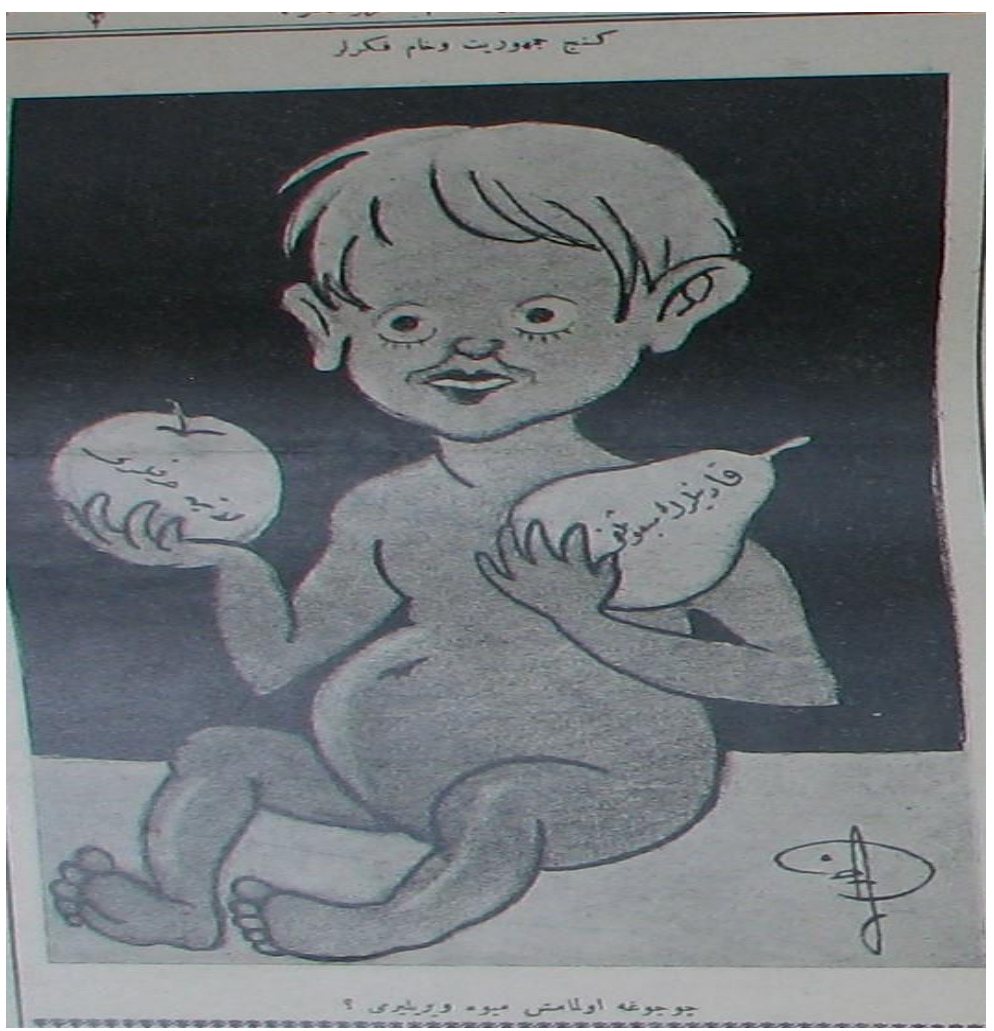

Caricature-3 (Tahir, 1924)

\section{Translation of Caricature}

Cover Letter: Young Republic and Raw Ideas

Apple in child's hand: Latin Letters

On pear: Women's Deputy

Subtitle: Is the child given unripe fruit?

\section{About Caricature-3}

When we examine the humor publications of the period, we see that the most critical publications are on women's parliamentary issues with the Letter Revolution. Ghazi Mustafa Kemal ensured that these revolutions were discussed by the public and prepared public opinion with the studies carried out in this direction. During this period, he realized that there was no question of public and press acceptance to this Letter Revolution (Turan, 2018: 387). As it is drawn in Caricature 3, 'latin letters' are written on the apple in child's hand and on the pear, 'women's deputies' are written. In this cartoon drawn on March 20, 1924, it can be understood from the question "Is the child given unripe fruit?", the people of Turkey and illustrators see the two reforms that are thought to be made as raw. 


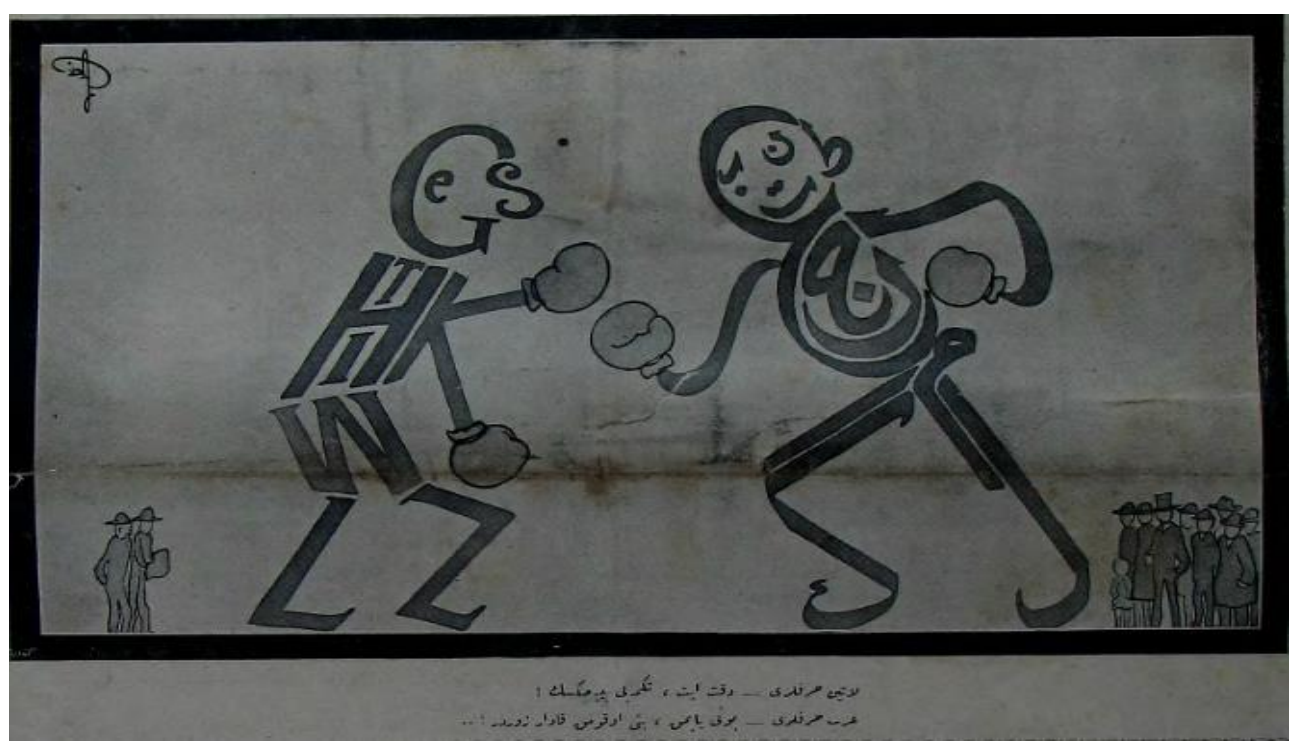

Caricature-4 (Gökçe, 1926)

\section{Translation of Caricature}

Latin Letters: Watch out you're gonna get kicked!

Arabian Letters: Doing this is as hard as reading me!...

\section{About Caricature-4}

Ramiz Gökçe draws Latin and Arab letters in a boxing match with each other and tries to show the difficulty of reading the Arabic letters to the public. This caricature was published at times when the Letter Revolution was not accepted. The most striking part of the caricature is the crowd of people behind the Latin letters and the Arabic letters. While 2 people stand behind the Latin letters, many people are drawn behind the Arabic letters. From this image, it is understood that the Latin letters were not fully adopted by the people in 1926 and the Letter Revolution was not accepted. Akbaba magazine and caricaturist Ramiz Gökçe tries to show the difficulty of reading the Arabic letters to the public, and the attitude of the magazine's publications from the Letter Revolution is clearly seen. 


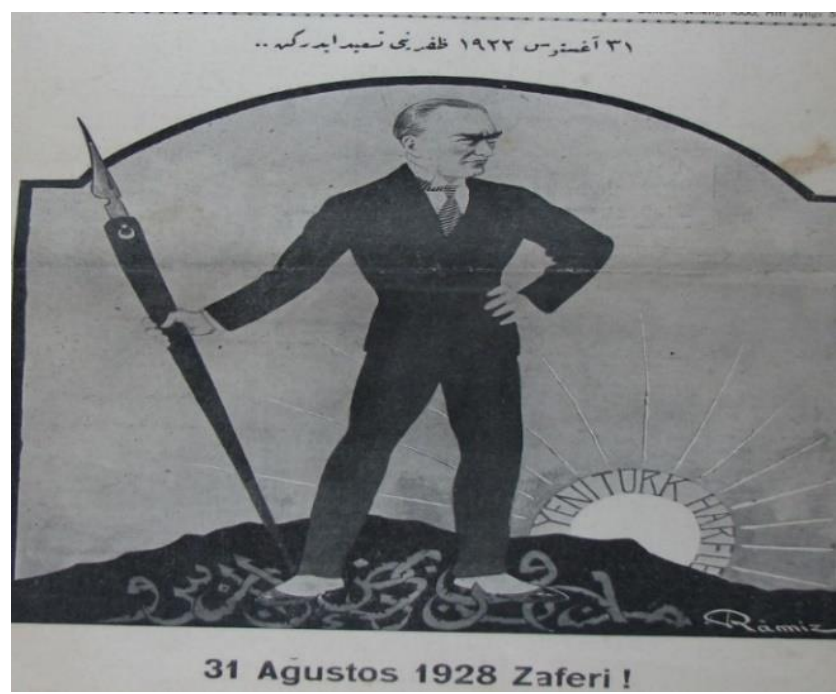

Caricature-5 (Gökçe, 1928)

\section{Translation of Caricature}

Cover Letter: Describing the August 31 Victory Day.

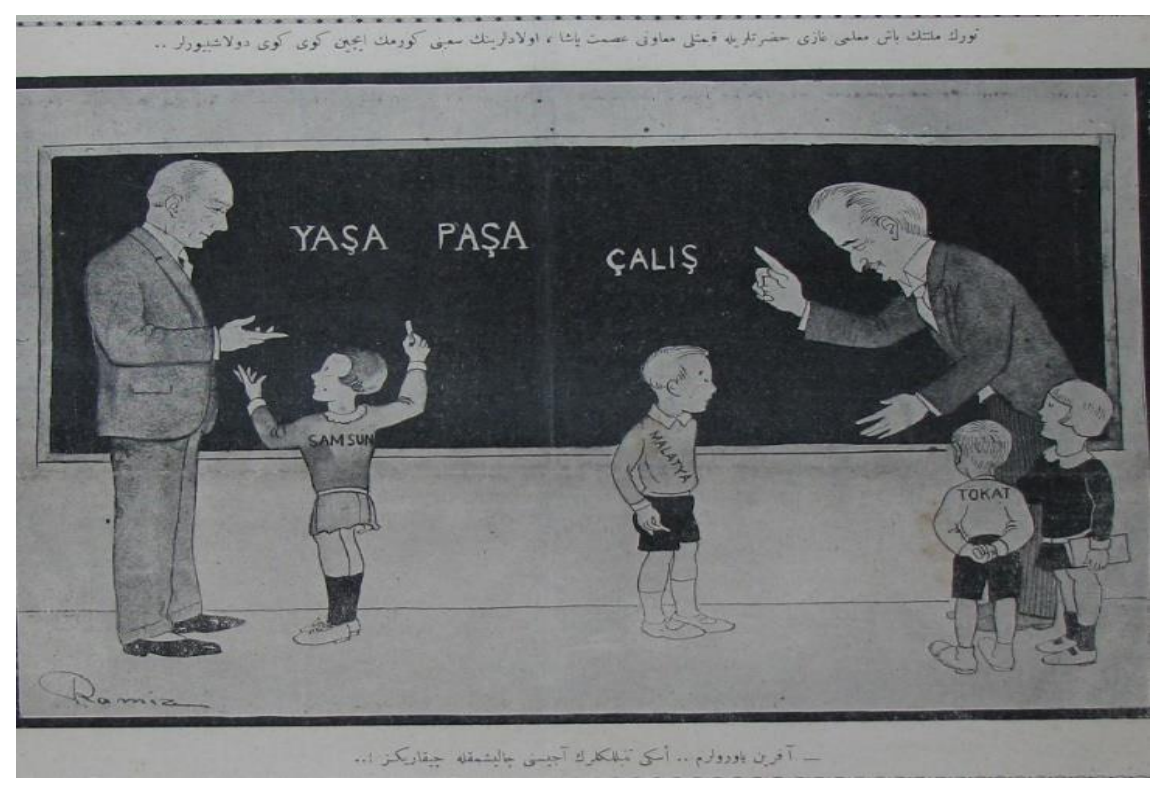

Caricature-6 (Gökçe, 1928)

\section{Translation of Caricature}

Cover Letter: The chief teacher of the Turkish Nation, His Holiness Gazhi and his precious assistant Ismet Pasha, wander from village to village to see the sain of their children...

Subtitle: Well done my children... Remove the pain of old laziness by studying. 


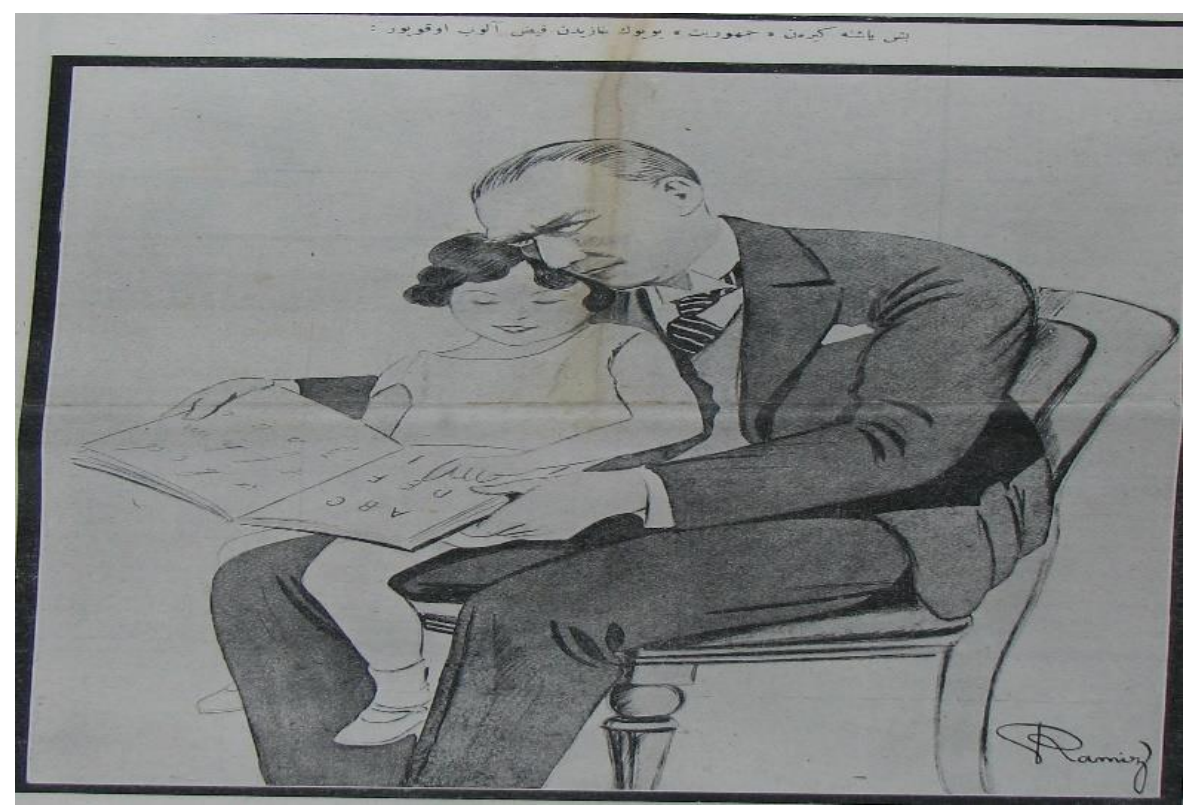

Caricature-7 (Gökçe, 1928)

\section{Translation of Caricature}

Cover Letter: "Cumhuriyet", who is five years old, takes Feyz from the Great Veteran and reads it.

\section{About Caricature-5, 6 and 7}

In Cartoon 5, Ghazi Mustafa Kemal holds the pen in his right hand by pressing on the old Arabic letters. New Turkish letters are written in the sun rising from the back of the cartoon. In addition to the August 31 Victory Day celebrated after the Independence War, the acceptance of Latin letters by leaving the Arabic letters on the same date is shown as victory. In this caricature, the adoption of Latin letters is depicted as the Republic which was liberated from enemy occupation.

In Caricature 6 and 7 it is important to show the importance of the transition to Latin letters. President Ghazi Mustafa Kemal and Prime Minister İsmet İnönü were drawn while teaching Latin letters to students and these drawings showed the importance given to the Letter Revolution by both the government and publishers. 


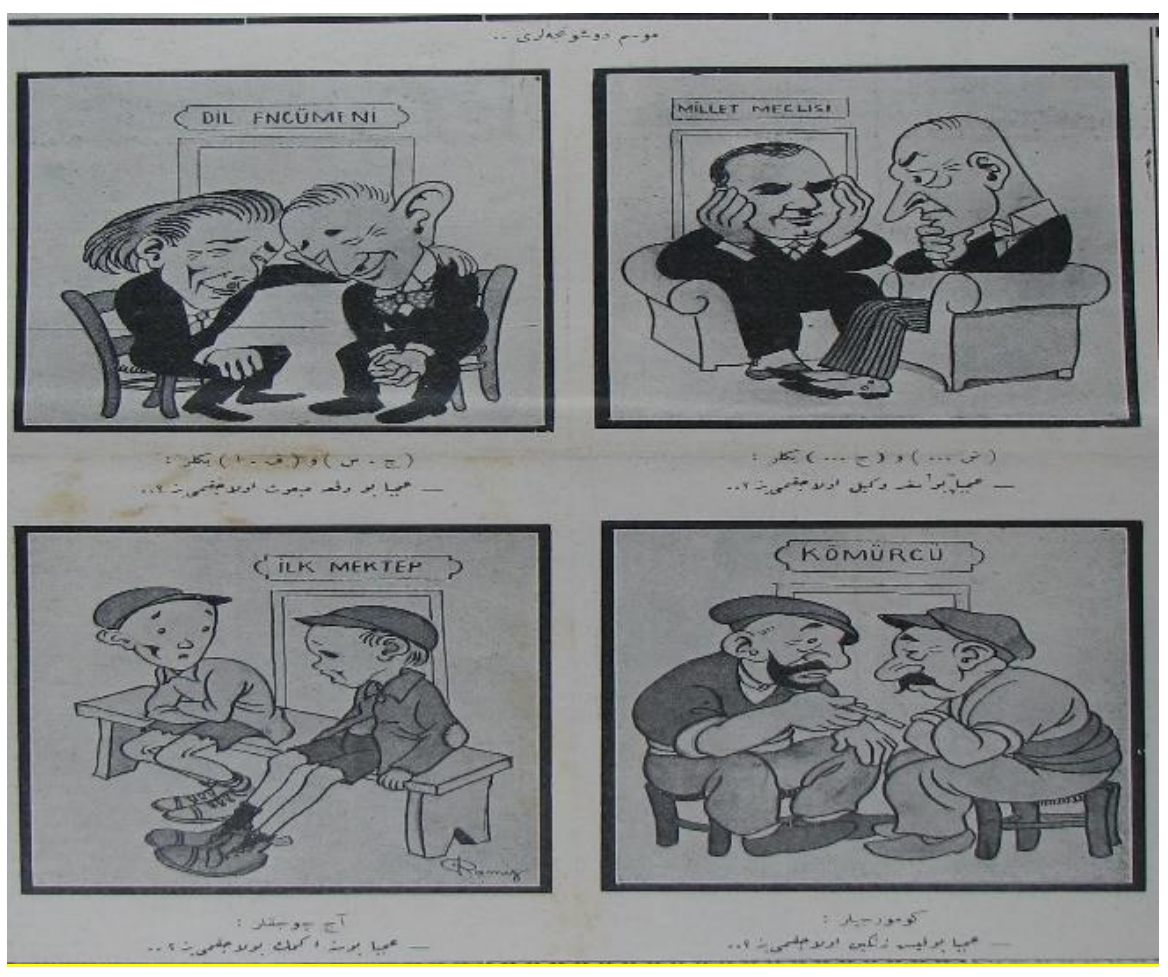

Caricature-8 (Gökçe, 1928)

\section{Translation of Caricature}

Cover Letter: Season Thoughts.

Subtitle of Language Committee Caricature:

(Arabic letters Cim and Sin) and (Elif and fe Letters) Gentlemen:

-“Are we going to be deputy this time?"

Subtitles for National Assembly caricature:

(Arabic Şın letter) and (Arabic Cim letter) Gentlemen:

-“Are we going to be proxy this time?"

Subtitles of First School caricature:

Hungry Kids: “Are we going to find bread this year?"

Subtitles of the coal dealer caricature:

Coal Dealers: "Are we going to be rich this winter?" 


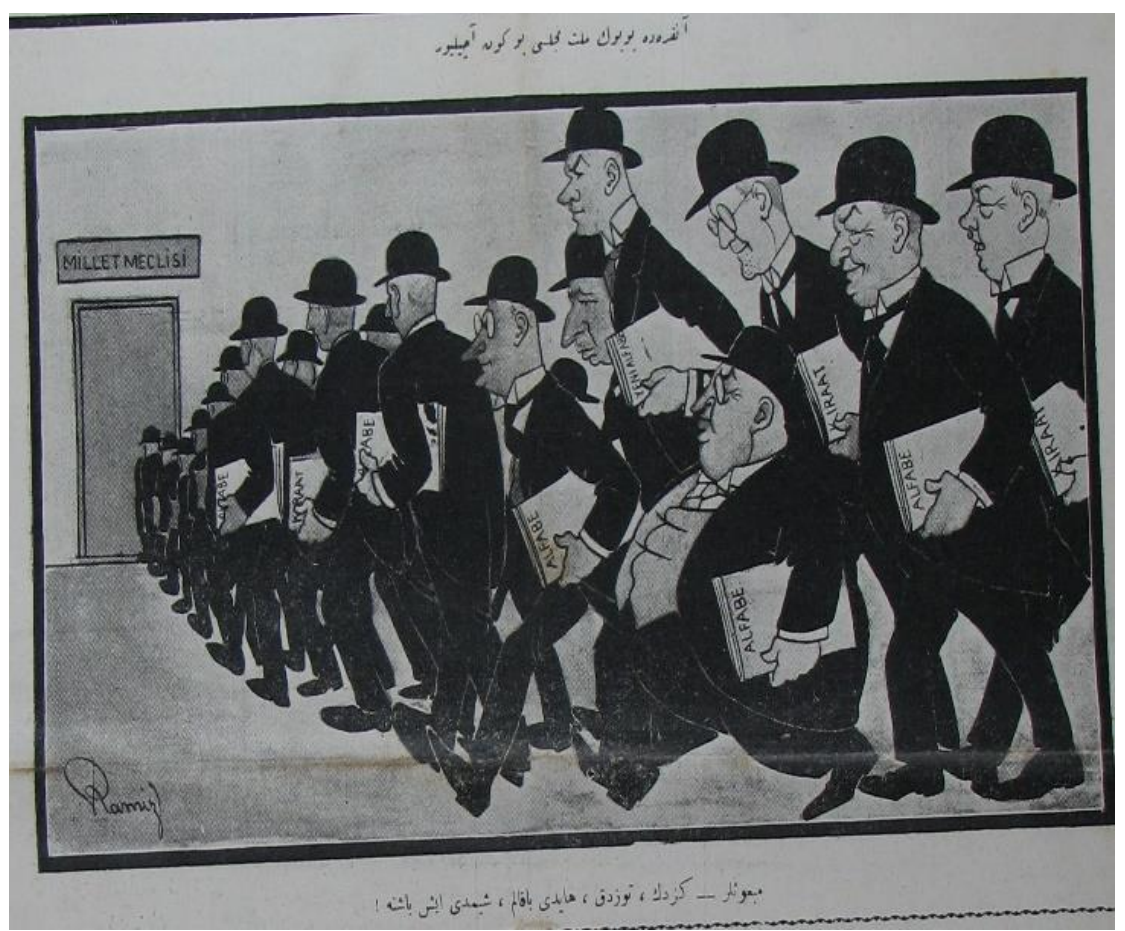

Caricature-9 (Gökçe, 1928)

\section{Translation of Caricature}

Cover Letter: Ankara Grand National Assembly is opening today.

Subtitle: Deputies - "We go around, for an outing, come on, get to work now!"

\section{About Caricature 8-9}

In caricature number 8 , there are some sections affected by the Letter Revolution. These groups reveal the state of society. People in the Language Council, which is considered to be a pioneer of the Letter Revolution, are waiting for post-revolution deputies. The deputies in the national assembly expect to be a member of parliament again together with the Letter Revolution has been successfully passed. The most important things are the students' statement who are educated in school "can we find bread?" and the thoughts of coal dealers " will we be rich?". Caricature illustrator Ramiz Gökçe vilifies the people, who made Letter Revolution, because of pursuing the position, and mentions about the people's desire to get rid of hunger and earn money rather than the Letter Revolution.

In caricature number 9, there is a satire, though small. Because the opening of the National Assembly, all the MPs have one idea, "Letter Revolution." However, as in Caricature 8, it is seen in this issue of Akbaba Magazine that the real expectation of the people is material issues. 


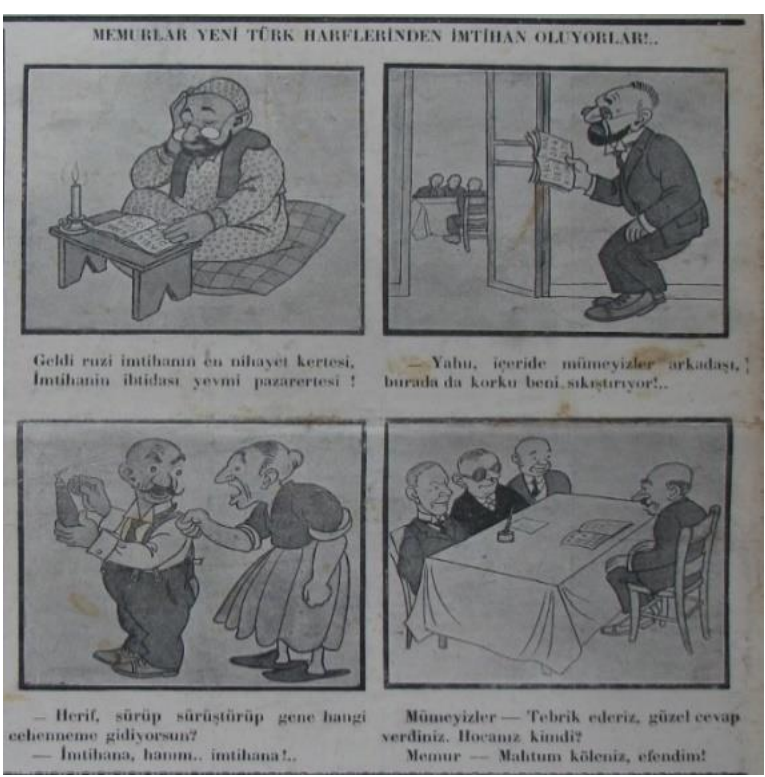

Caricature-10 (Karikatür, 1928)

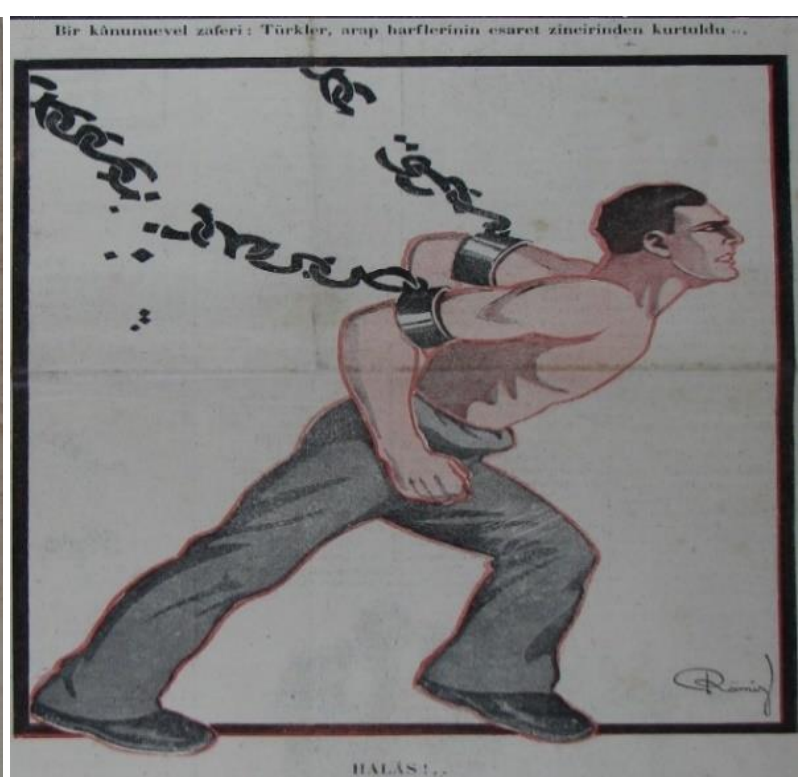

Caricature-11 (Gökçe, 1928)

\section{About Caricature 10-11}

Speciality of Caricature 10 and 11 are written in Latin letters. It is seen that newspapers and magazines started to be published in Latin letters which came into force on 3 November 1928 (Inan, 2018: 185).Although it is still in November, it is also seen in the Caricature number 10 where the civil servants are subjected to an exam. In caricature number 11, the person tied with the chain gets rid of the chains. The chain here is the Arabic letters. Under the cartoon is written halas that means over. Akbaba's view is clearly seen about Latin letters with this caricature. 


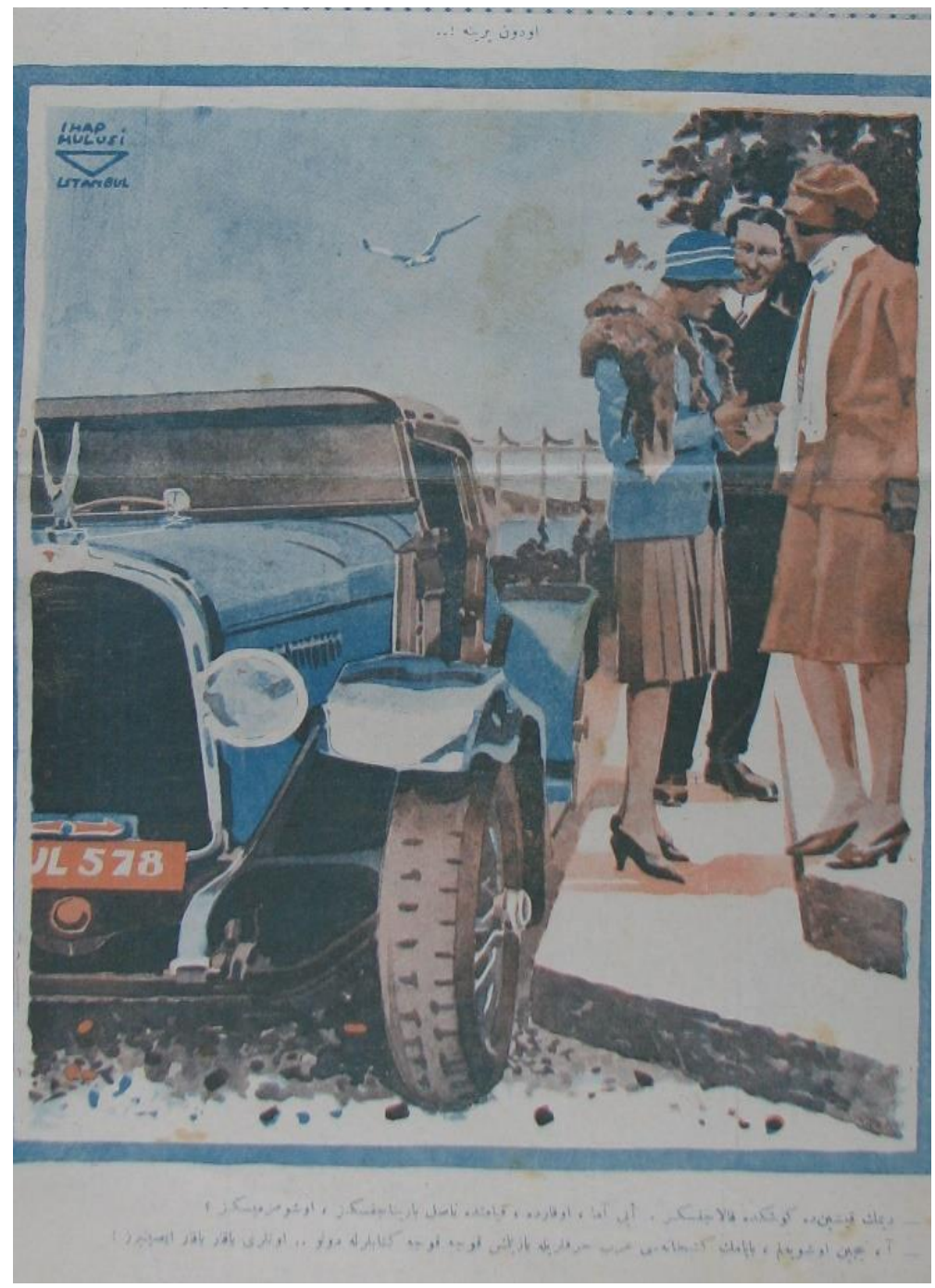

Caricature-12 (Görey, 1928)

\section{Translation of Caricature}

Cover Letter: Instead of Wood!...

Subtitle: "So you will stay in the mansion during the winter. But how are you going to shelter in that snow, don't you get cold?"

"Oh, why do we get cold, my father's library is full of huge books written in Arabic letters... We burn them up and warm!"

\section{About Caricature-12}

The reason for using this caricature is the speeches in the subtitle of the caricature. The adoption of the Arabic alphabet and the transition to the Latin alphabet has been adopted so quickly that books written in Arabic letters 
are thought to be burned only for warmth without considering the importance. Caricature illustrator Ihap Hulusi clearly shows us the perspective of the people of a part of the period to the Arabic letters with this caricature.

\section{RESULT}

Cartoons are important arguments that reveal their critical identity with humor of the period in which they lived. Examining these printed media organs in public broadcasts by discussing the problems of today's political and social life means taking some kind of x-ray. The mission of humor and cartoon magazines in the Early Republic period is very important in terms of revealing the mental structure of the government and the people of the period. The fact that the government, which came to power after the War of Independence ended successfully, would turn to innovation and reforms with the idea of radical change, with the approval of the National Will that was with it in all circumstances. The attitude of the tired people who lived the First World War and the War of Independence against the changes that would have been experienced in centuries would have been a serious obstacle to the new state to be established.

With the loss of the war at the end of the First World War and the invasion of Anatolia by the Entente States, a sad and hopeless period began in Ottoman society. With the first steps of the National Struggle on May 19, 1919, the beginning of the long and arduous road, the hope of the people to get rid of the invasion of the Entente States has flourished. In this environment, reaching news everywhere in Anatolia and raising public awareness could be done through printed publications, which were the only news source of the time. Considering its impact on the public, printed publications are of great importance. Similarly, considering the claims of low literacy of the period, the importance of visuals in printed publications increases. Therefore, cartoon writers and cartoonists have great responsibility.

With the success of the National Struggle, serious innovation and reform movements have begun throughout the country. There have been many revolutions that have influenced education, law, economic and everyday life. Considering the low literacy rate, it is thought that the public is seriously affected by the print media. In this context, how the Law of Tevhid-i Tedrisat, which is the subject of the article, and how the Letter Revolution was used in the humor magazines and newspapers of the period was investigated and in this context Zümrüd-ü Anka and Akbaba magazines were examined. Today, it is possible to learn through the humor and cartoon magazines that some of the Revolutions that still cause controversy among the public or political channels have had an impact on the public in the Early Republican period. Tevhid-i Tedrisat Law and Letter Revolution, which is one of the important reforms of the Republican era, is an innovation that has been tried to form a public opinion for a long time. It is known that Gazi Mustafa Kemal himself asked the reforms that were in the period of maturation, in every environment he was with, and kept the pulse of the people. In the first years of the establishment of the Republic of Turkey, it is believed to undermine the national unity of the will of the people all matters not provided the union. 
We have examined within the framework of the Law on Unification of Education and Letter Revolution, it has been seen that no significant criticism was made against the government of the period in Zümrüd-ü Anka and Akbaba humor magazines (Cantek \& Gönenç, 2017: 13). There are two reasons for this situation. The first is that the public and the media support the Ankara government against the Allied states and the Istanbul Government. The second reason is that there is a period of joy in the public and in the press as the National Struggle succeeds.

Akbaba newspaper is regarded as the flagship of humor magazines of the period. When we examine the issues at Akbaba magazine, it is seen that there is no serious satire or criticism towards the Unification of Education Law and Letter Revolution. The main reason for this situation is the close relations of Akbaba magazine with political powers throughout its publishing life. It was claimed that he received material incentives in line with his criticism of the opposition (Cantek \& Gönenç, 2017: 12).

When the publications published by Zümrüd-ü Anka during his two-years life are examined, it is difficult to find information and caricatures about the Law of Tevhid-i Tedrisat and the Letter Revolution. In the magazine, we see the publication on the subject of Tevhid-i Tedrisat in the first caricature. There is no criticism in this caricature. However, in the third caricature, as mentioned above, the little boy has apples and pears in his hands. In the apple, "Latin letters" and in the pear "Women's Deputy" is written. In the top title, "Young Republic and Raw Ideas" is written. Ratib Tahir, the caricaturist of Zümrüd-ü Anka, thinks that the adoption of Latin letters is new and raw. On the other hand, although it is a small criticism, the other aspect of this caricature is that a more immature fruit, such as the "Latin Letter and the Women's Deputy" are expected to mature.

Among the reforms that are still the subject of controversy today, Tevhid-i Tedrisat Law and Letter Revolution has been chosen to examine whether there are any criticisms of the cartoonists and printed publishers of the period against the reforms made in the beginning of the Republic. Today, caricatures, which are seen as the source of criticism and satire, have been examined in a period of allegedly low literacy, and Zümrüd-ü Anka and Akbaba magazines have been examined and no serious criticism has been found.

Innovation and reform movements are painful periods for states. Although these processes are made with the need, it is possible to criticize and discuss the years without considering the conditions of the period. During the early Republican period, the press stood beside its state after all the experiences, and played an important role in public disclosure of reforms and innovations. It was not only reflected on the pages of printed publications and newspapers, but also the Republican era and innovations that affected humor and cartoonists (Yetim \& Akkoyunlu, 2017: 96).

\section{ETHIC}

In this article, journal writing rules, publishing principles, research and publishing ethics rules, journal ethics rules are followed. I am responsible for any violations that may arise in the article. 


\section{REFERENCES}

Acar, A. (2012). Türkiye'de Latin Alfabesine Geçiş Süreci ve Gazeteler. Iletişim Fakültesi Dergisi, 5-25.

Arı, A. (2002). Tevhid-i Tedrisat ve Laik Eğitim. Gazi Eğitim Fakültesi Dergisi, 181-192.

Arık, B. (2002). Karikatür Tarihimizde Önemli Bir Dönemeç: Marko Paşa Gazetesi. İstanbul Üniversitesi iletişim Fakültesi Dergisi, 237-253.

Atatürk, K. (2009). Nutuk 1919-1927. (Z. Korkmaz, Ed.) Ankara: Atatürk Araştırma Merkezi.

Avcı, C. (2013). Harf İnkılabı ve Millet Mektepleri. Akdeniz Insani Bilimler Dergisi, 43-60.

Baykara, T. (2011). Türk Inkılap Tarihi ve Atatürk Ilkeleri. İstanbul: IQ Kültür Sanat Yayıncılık.

Berrak, A. (2012). Durum Çalışmasına Ayrıntılı Bir Bakış. Adnan Menderes Üniversitesi Eğitim Fakültesi Eğitim Bilimleri Dergisi, 1-9.

Büyüköztürk, Ş., Çakmak, E. K., Akgün, Ö. E., Karadeniz, Ş. \& Demirel, F. (2018). Bilimsel Araştırma Yöntemleri. Ankara: Pegem Akademi Yayınları.

Cantek, L. \& Gönenç, L. (2017). Muhalefet Defteri Türkiye'de Mizah Dergileri ve Karikatür. İstanbul: Yapı Kredi Yayınları.

Çepni, S. (2005). Araştırma ve Proje Çalışmalarına Giriş. Trabzon.

Çeviker, T. (2010). Karikatürkiye Karikatürlerle Cumhuriyet Tarihi 1923-2008. İstanbul : NTV Yayınları.

Çeviker, T. (2010). Karikatürkiye Karikatürlerle Cumhuriyet Tarihi 1923-2008. İstanbul: NTV.

Ertan, T. F., Aysal, N., Bakacak, A., Dinçer, H. \& Unat, K. (2018). Başlangıcından Günümüze Türkiye Cumhuriyeti Tarihi. Ankara: Siyasal Kitabevi.

Gökçe, R. (1924, Mart 13). (133). Akbaba Dergisi.

Gökçe, R. (1926, Nisan 5). (348). Akbaba Dergisi.

Gökçe, R. (1928, Ağustos 30). (598). Akbaba Dergisi.

Gökçe, R. (1928, Eylül 17). (602). Akbaba Dergisi.

Gökçe, R. (1928, Ekim 29). (614). Akbaba Dergisi.

Gökçe, R. (1928, Ekim 22). (612). Akbaba Dergisi.

Gökçe, R. (1928, Kasım 1). (615). Akbaba Dergisi.

Gökçe, R. (1928, Kasım 29). (623). Akbaba Dergisi.

Görey, İ. H. (1928, Kasım 4). (607). Akbaba Dergisi.

Günal, Z. (2008). Atatürk Ilkeleri ve Inkılap Tarihi (XVII.-XIX. Yüzyıl Islahat Hareketlerinden 1938'e.

Ankara: Nobel Yayın Dağıtım.

Hünerli, S. (1993). Türkiye'de Gazete Karikatürünün Durumu ve Siyasi Karikatürün Söylemi. İstanbul: İstanbul Üniversitesi.

Hünerli, S. (1993). Türkiye'de Gazete Karikatürünün Durumu ve Siyasi Karikatürün Söylemi. İstanbul: İstanbul Üniversitesi. 
İnan, A. (2018). Türkiye Cumhuriyeti ve Türk Devrimi. Ankara: Türk Tarih Kurumu.

IRCICA. (2019, MayIs 11). e-library. From IRCICA: https://e-library.ircica.org/

Karataş, Z. (2015). Sosyal Bilimlerde Nitel Araştırma Yöntemleri. Manevi Temelli Sosyal Hizmet Araştırmaları Dergisi, 63-80.

Karikatür. (1924, Mart 13). (133). Akbaba Dergisi.

Karikatür. (1926, Nisan 5). (348). Akbaba Dergisi.

Karikatür. (1928, Kasım 12). (618). Akbaba Dergisi.

Karikatür. (1928, Ağustos 30). (598). Akbaba Dergisi.

Kaya, M. \& Acarlı, M. (2018). Cumhuriyet'in İlk Yıllarına Kadar Türkiye'de Karikatürün Tarihsel Gelişimi. Milli Kültü Araştırmaları Dergisi, 127-133.

Kaya, M. \& Acarlı, M. (2018). Cumhuriyet'in İlk Yıllarına Kadar Türkiye'de Karikatürün Tarihsel Gelişimi. Milli Kültür Araştırmaları Dergisi, 127-133.

Kayış, Y. (2004). Demokrat Parti Iktidarı Döneminde Siyasi Karikatür. İzmir: Dokuz Eylül Üniversitesi. Kayış, Y. (2004). Demokrat Parti İktidarı Döneminde Siyasi Karikatür. İzmir: Dokuz Eylül Üniversitesi. Kocatürk, U. (2000). Atatürk ve Türkiye Cumhuriyeti Tarihi Kronolojisi 1918-1938. Ankara: Türk Tarih Kurumu Basımevi.

Öğdü, H. (2011). Türk Siyasal Hayatının Karikatür Üzerinden Analizi: Akbaba Dergisi Örneği. Konya: Selçuk Üniversitesi.

Öngören, F. C. (1998). Cumhuriyetin 75. Yılında Türk Mizahı ve Hicvi. İstanbul: Türkiye İş Bankası Yayınları.

Sakin, S. (2011). Siyasi Karikatürlerde Emperyalizm Milletler Cemiyeti ve Türkiye. İstanbul: IQ Kültür Sanat Yayıncılık.

Subaşı, M. \& Okumuş, K. (2017). Bir Araştırma Yöntemi Olarak Durum Çalışması. Atatürk Üniversitesi Sosyal Bilimler Enstitüsü Dergisi, 419-426.

Tahir, R. (1924, Mart 6). (121). Zümrüdü Anka Dergisi.

Tahir, R. (1924, Mart 20). (120). Zümrüdü Anka Dergisi.

Tonga, N. (2008). Türk Edebiyatı Tarihinde Mühim Bir Mecmua: Akbaba (1922-1977). Turkish Studies Dergisi, 665-679.

Turan, E. T. (2018). Mustafa Kemal Paşa Ve Harf İnkılâbı. Vakanüvis - Uluslararası Tarih Araştırmaları Dergisi, 380-397.

Us, H. T. (2019, Nisan 27). Hakkı Tarık Us Dijital Koleksiyonu. From Hakkı Tarık Us Dijital Koleksiyonu: http://www.tufs.ac.jp/common/fs/asw/tur/htu/

Yetim, F. \& Akkoyunlu, S. B. (2017). Türk Modernleşmesine Erken Cumhuriyet Dönemi Basınında Karikatür Üzerinden Bir Bakış, , 3/3, (2017), 93. Tarih ve Gelecek Dergisi, 77-96. 
Yıldırım, A. \& Şimşek, H. (2005). Sosyal Bilimlerde Nitel Araştırma Yöntemleri. Ankara: Seçkin Yayınları.

Yılmaz, H. (2016). 1923 Yılı Mizah Basınında Kadınların Seçme-Seçilme Hakkı ve Kadınlar Halk Fırkası. Atatürk Üniversitesi Türk Inkılap Tarihi Enstitüsü Atatürk Yolu Dergisi, 263-296.

Yılmaz, N. F. (2017). 1923 Nüfus Mübadelesine Mizah Penceresinden Bakmak: Zümrüdü-anka. Uluslararası Tarih Araştırmaları Dergisi, 76-91.

Zengin, Z. S. (2002). Tevhid-i Tedrisat Kanunu'nun Hazırlanmasından Sonraki Illk Dönemde Uygulanışı ve Din Eğitimi. Dini Araştırmalar Dergisi, 81-106. 


\section{TEVHID-i TEDRISAT KANUNU VE HARF INKILABI DÖNEMIN MIZAH DERGILERINDE NASIL IŞLENMIŞTIR?}

öz

Türkiye Cumhuriyeti Devleti, Osmanlı Devleti'nden almış olduğu mirası yenilik ve reform hareketleri ile ileriye taşımak istemiştir. Milli Mücadele döneminde yaşanan sıkıntılar nedeniyle yeni bir devletin kurulması halkta ve görsel medyada sevinç döneminin yaşanmasına neden olmuştur. Bu sevinç döneminde yapılmış olan yenilik ve reform hareketleri yüzyıllardır süregelen toplum yapısını ve müesselerini kökünden değiştirmiştir. Eğitim, hukuk, ekonomik ve gündelik yaşamı etkileyen birçok inkılap hayata geçirilmiştir. Düşük okuryazarlık oranı dikkate alındığında, halkın yazılı basından ciddi şekilde etkilendiği düşünülmektedir. Değişimlerin içerisinde önem arz eden, Tevhid-i Tedrisat Kanunu ve Harf İnkılabı'nın, mizah dergileri vasıtasıyla halkın üzerindeki etkisi araştırılmıştır. Bu minvalde, Tevhid-i Tedrisat Kanunu ve Harf inkılabı çerçevesinde incelenen Zümrüd-ü Anka ve Akbaba mizah dergilerinde, 1924-1928 yılları arasında ki yayınlar baz alınarak dönemin hükümetine karşı kayda değer eleştiride bulunulmadığı görülmektedir. Özellikle yenilik ve reform hareketlerine yönelik yapılan yayınlarda mizah dergi ve gazetelerinde çizerlerin bu inkılapları destekleyici yayınlar yaptıkları çalışmadan anlaşılmaktadır.

Anahtar Kelimeler: Zümrüd-ü Anka Dergisi, Akbaba Dergisi, Tevhid-i Tedrisat Kanunu, Harf İnkılabı. 


\section{Giriş}

Tarih anlatımı yazılı, sözlü ve görsel olmak üzere üç ana hat üzerine kuruludur. Yazılı ve sözlü tarih anlatımını tamamlayan unsur ise görsel materyallerdir (Sakin, 2011: 11). Insanlar duygu ve düşüncelerini eski çağlardan itibaren anlatmak için farklı metotlar kullanmışlardır. Eski Mısır, Roma, Hitit, Yunan ve diğer doğu kültürlerinde çizim, kabartma, heykel ve bunlara benzer taş üzeri görsel çizimlere ulaşmak mümkündür (Kayış, 2004: 4). 19. yy. da kullanılmaya başlanan basııı görsel materyaller çağın ilerlemesi ile birlikte toplumların dikkatini çeken en önemli haber kaynaklarından biri olmaya başlamıştır.

Osmanlı Devleti'nde gazete ve dergilerde karikatür kullanımı batılı ülkelerde olduğu gibi basımevlerinin kurulması ile birlikte ortaya çıkmıştır. Fotoğraf kullanımının daha başlamadığı dönemlerde, bugün karikatürist dediğimiz çizerler, dönemin olaylarına mizah katarak olayları halka anlatmaya çalışmışlardır (Arık, 2002: 238). El mahareti ile kaleme alınan mizah ürünü karikatürler okuryazar kesimin azlığı nedeniyle halk arasında belli bir itibar kazanmıştır. Halk özellikle bu tür yayınları takip ederek ülke içerisinde olan olaylar hakkında bilgi edinmekte, güncel meseleleri mizah yoluyla öğrenebilmektedir. Mizah yayınları dönem koşullarının esnekliğine göre, siyasal ve toplumsal olaylara eleştiri, alaya alma gibi ifadeler katılarak yayınlanmaya başlanmıştır (Arık, 2002 :239). Mizah ile çizilen siyasi karikatürler, okuyucuya ele alınan konuyu aktarmasının yanında, güldürürken düşündürmeyi de hedeflemiştir.

Osmanlı Devleti'nde karikatür ilk olarak Tanzimat Döneminde kullanılmışıı. Kanuni Esasi'nin ilanına kadar mizah basını yayınlarına devam etse de bir süre sonra yayınlarda azalma olduğu görülmüştür. Ancak II. Meşrutiyetin ilanından sonra ise mizah gazeteleri ile mizah dergilerinin sayılarında önemli bir artış olmuştur (Hünerli, 1993: 28). 30 Ekim 1918'de Mondros Ateşkes Antlaşmasını imzalayan Osmanlı Devleti I. Dünya Savaşı'nda mağlup olduğunu kabullenmiş ve toprakları işgal edilmeye başlanmıştır. Haliyle bu dönem sonrasında kullanılan karikatürler ile mizah dergilerindeki yayınlar genellikle işgal devletlerine karşı Kurtuluş Savaşını ve Anadolu'da Milli Mücadele için çaba sarf eden Ankara Hükümet'ini konu almıştır. Bu dönem yayın yapan gazeteler çalışmalarını bir asker gibi kullanmakta, basılı görselleri ve yayınları ise birer silah gibi kullanmışlardır. Dönemin basınında işgal devletlerinden taraf olan yayınlar olsa da mizah basını milli mücadelenin halka anlatımında önemli bir sorumluluk yüklenmiştir (Kaya \& Acarlı, 2018 :132).

Kurtuluş Savaşı'nın başarı ile sonuçlanması ve toprakların düşman işgalinden kurtarılması ile birlikte basın kuruluşlarının tamamı başarıyı öven ve milliyetçi düşünceleri öne çıkaran yayınlar yapmaya başlamışlardır. Bu dönemde mizah dergisi olarak yayın yapan 21 dergi bulunmaktaydı. Başlıca dergiler şunlardır: "Karagöz (19081950), Diken (1918-1919), Güleryüz (1921-1923), Aydede (1922), Ayine (1921-1923), Akbaba (1922-1977), Zümrüd-ü Anka (1923-1925), Kelebek (1923-1924)” (Çeviker, 2010: 21).

23 Nisan 1920'de Türkiye Büyük Millet Meclisi'nin açılması sonrasında (Günal, 2008: 230) Kurtuluş Savaşı́ndan da başarı ile çıkan Ankara Hükümeti, 24 Temmuz 1923 yılında Lozan Barış Antlaşması'nı imzalayarak, Milli 
Mücadele'yi nihayetlendirmiştir (Baykara, 2011: 164). Lozan Barış Antlaşması'nın imzalanması sonrasında işgal güçlerinin İstanbul ve diğer Anadolu topraklarını terk etmesi ile birlikte ülkede yeni dönem başlamıştır.

29 Ekim 1923'te Cumhuriyet'in ilanı ile birlikte karikatür ve mizah basını için yeni bir dönem başlamıştır. Özellikle bu dönem ile birlikte alınan yenilik kararları, basılı medyada önemli oranda karikatürlere ve görsel yayınlara yansımıştır. 3 Kasım 1928 Harf İnkılabı ile birlikte Arap alfabesinin terk edilmesi ve yerine Latin harflerinin kullanılmaya başlanması ile yazılı basın hayatı için yeni bir dönem başlamıştır (Öngören, 1998: 73). 1923-1928 yılları arası dönemin basın-yayın hayatı için en önemli özelliği Osmanlıca'nın Arap harfleriyle yazılmasıdır. Ayrıca bu dönemin diğer bir özelliği ise, Milli Mücadele’nin başarı ile sonuçlanması ile birlikte halkta mutluluğa basında ise özgür bir döneme neden olmasıdır (Öngören, 1998: 76).

Cumhuriyet dönemi ile birlikte gazetelerin önemli bir bölümü sayfalarında karikatürlere, çizimlere yer vermeye devam etmiştir. Erken Cumhuriyet dönemi karikatür yayınını ikiye ayırmak gerekmektedir; 1. dönem, 29 Ekim 1923 Cumhuriyetin ilanından 3 Kasım 1928 Harf İnkılabına kadar olan dönemdir. 2. dönem ise Harf İnkılabından, 21 Temmuz 1946 seçimleri ile birlikte çok partili hayata geçiş olarak kabul edilmektedir. Bu dönem de genel itibariyle çizerlerin karikatür sanatını rahat bir şekilde kullandıkları ve anlatımlarını çizime döktükleri dönem olarak kabul edilmektedir (Çeviker, 2010: 22).

\section{AMAÇ}

Bu çalışma, Kurtuluş Savaşı'ndan başarı ile çıkan Türkiye Cumhuriyeti'nin kuruluş aşaması sayılan bu dönemde, mizah ve karikatür dergilerinin, Tevhid-i Tedrisat Kanunu ve Harf İnkılabı'na bakış açılarını araştırmayı ve incelemeyi amaçlamıştır. Bu çerçevede aşağıda yer alan alt sorulara, problemlere çözümler aranmıştır:

1. Mizah basınında dönemin özellikleri nasıl yansıtılmaktadır?

2. Cumhuriyet'in ilk dönemlerinde mizah yayınlarında, Tevhid-i Tedrisat Kanunu ve Harf İnkılabı nasıl işlenmiştir?

3. Tevhid-i Tedrisat Kanunu ve Harf İnkılabı bağlamında incelenecek olan Akbaba ve Zümrüd-ü Anka dergileri nasıl bir siyasi tutum sergilemiştir?

\section{YÖNTEM}

Bu çalışmada araştırma yöntemlerinden, "durum çalışması yöntemi” kullanılmıştır. Nitel bir araştırma yöntemi olan durum çalışması; bir veya birden fazla olayın, olgunun veya sınırlı bir sistemin, derinlemesine araştırılmasına ve betimlenmesine yönelik yapılan çalışmalarda kullanılmaktadır (Büyüköztürk vd., 2018: 60; Karataş, 2015: 63). Durum çalışması; veri toplama, toplanan verileri planlama, bulgulara ulaşma ve bu bulguları yorumlamayı amaçlayan sistemli bir çalışma desenidir (Berrak, 2012: 3). Yapılan çalışmada dönemin şartları göz önünde bulundurularak, bazı mizah dergilerinin Tevhid-i Tedrisat Kanunu ve Harf İnkılabı hakkında yapmış oldukları yayınların değerlendirilmesi ve olaylar arasında ilişkinin incelenmesi nedeniyle nitel veri analizi yöntemlerinden “Betimsel Analiz Yöntemi” kullanılmıştır. Betimsel analizde amaç, elde edilen verileri düzenleyip yorumlayarak 
okuyucuya sunmaktır. Bu doğrultuda elde edilen veriler düzenlenerek sistemli ve açık bir şekilde betimlenmeye çalışılmıştır. Elde edilen veriler betimlenerek yorumlanmaya çalışıımışır. Son olarak neden-sonuç ilişkisi içerisinde incelenerek sonuçlara ulaşılmıştır (Yıldırım ve Şimşek, 2005: 224).

Bu çalışmada bir döneme ait görsel yayınların dönemin gelişmelerini nasıl algıladıklarının tespit edilmesi amaçlanmıştır. Bu çerçevede, çalışma için durum çalışması yöntemlerinden betimsel analiz yönteminin kullanılmasının bu çalışmanın yapısına uygun olduğu düşünülmüştür. Çalışma için gerekli doküman ve belgeler, Beyazıt Devlet Kütüphanesi, İslam Tarih, Sanat ve Kültür Araştırmaları Merkezine(IRCICA) ait Farabi dijital kütüphanesi ile Hakkı Tarık Us Koleksiyonu olarak bilinen ve dijital ortama aktarılmış bulunan gazete ve dergilerin incelenmesi sonucunda elde edilmiştir.

\section{DÖNEMIN BAŞLICA MIZAH-KARIKATÜR DERGILERI}

\section{a) Akbaba Dergisi (1922-1977)}

Kurtuluş Savaşı́nın yapıldığı dönemde Türk karikatür ve mizah dergileri açııından Aydede ve Güleryüz dergileri yayın hayatına devam etmekteydi. Güleryüz dergisinin kurucusu Sedat Simavi, Ankara Hükümeti'ni destekleyen yayınlar yapmaktayken, Aydede dergisinde ise Refik Halid Karay İstanbul Hükümeti'ni destekleyen yayınlar yapmaktaydı(Tonga, 2008: 666). Kurtuluş Savaşı'nın başarı ile tamamlanmasından sonra Refik Halid Karay ülkeden kaçmış, Aydede dergisi kapanmış ve yerine "Akbaba" dergisi Yusuf Ziya Ortaç tarafından kurulmuştur (Cantek ve Gönenç, 2017: 11). Türk karikatür ve mizah dergileri arasında en uzun süreli yayınlanan dergi Akbaba dergisidir. 55 yıllık yayın hayatında dergi üç defa kapanmıştır (Öğdü, 2011: 31) Kapanan Aydede dergisinin neredeyse bütün yayın kadrosu Akbaba dergisinde buluşmuştur. Akbaba Dergisi'nin başıca önemli çizerleri şunlardır: "Münif Fehim, Ramiz Gökçe, İsmail Hakkı, Hasan Rahim (Us), ihap Hulusi (Görey), Ratip Tahir Burak, Cemal Nadir Güler" (Sakin, 2011: 71).

\section{b) Zümrüd-ü Anka Mizah Dergisi (1923-1925)}

Cumhuriyet'in kurulmasından kısa süre sonra, 11 Ocak 1923 yılında kurulan Zümrüd-ü Anka mizah dergisi 23 Nisan 1925 tarihinde faaliyetlerine son vermiştir (Yılmaz, 2017: 77). Cumhuriyet döneminin kurulan ilk mizah dergisi olması bu dergiyi önemli kılmıştır. Pazartesi ve Perşembe olmak üzere haftada iki defa çıkarılan derginin yazar kadrosunda bulunan bazı yazarları şunlardır; “Orhan Seyfi (Orhon), Yusuf Ziya (Ortaç), Peyami Safa, Selami İzzet (Sedes), A. Lütfü". Karikatürist kadrosunda yer alan bazı önemli çizerler şunlardır; Ramiz (Gökçe), Zeki Cemal (Bakiçelebioğlu), İsmail Hakkı, Ahmet Münif (Fehim), Ratip Tahir (Burak), Cevat Şakir (Kabaağaçı), Hasan Fehmi (Us), Ahmet Rıfkı, Cemal Nadir(Güler)“(Yılmaz, 2016: 266). Semih Lütfi Erciyas'ın sahibi olduğu bu dergi Cumhuriyet'in ilk yıllarında yaşanan yenilik ve reform hareketlerini konu edinerek, dönemin kültürel ve toplumsal değişimini eleştirmiştir. Ancak Zümrüd-ü Anka dergisi yayın hayatına başladığı tarihten 2 yıl 3 ay sonra, 224. sayısı ile birlikte, Takrir-i Sükûn Kanunu'nun ilanından kısa süre sonra yayın hayatını noktalamıştır(Yılmaz N. F., 2017: 77). 


\section{TEVHID-i TEDRISAT KANUNU}

Türkiye Cumhuriyeti'nin kuruluşunun özellikle ilk on yıllık döneminde Osmanlı Devleti'nden devralınan mirasın temel dinamikleri üzerinde ciddi toplumsal ve yapısal değişim yapılırken, eğitim içinde reform yapılmaması beklenemezdi (Zengin, 2002: 81). Milli Mücadele döneminin nihayetlenmesi ile birlikte, Türkiye Cumhuriyeti'nde başlayan yenilenme hareketleri kapsamında, Arap alfabesinden üretilen "Osmanlı alfabesi”nin de yenilenmesi fikri İzmir iktisat kongresinde görüşülmüştür. Bu kongreden dört gün sonra, eğitim ve öğretim hayatının yeniden ele alınması ile ilgili 8 Mart 1923 tarihinde “Maarif Misakı” diğer adıyla “Eğitim Andı” (Ertan vd., 2018: 188) ilan edilmiştir.

Cumhuriyet'in ilanından sonra, Osmanlı Devleti döneminden bu yana devam eden medrese eğitiminin halkın okur-yazarlığına etkisinin az olduğu düşüncesi ve eğitim sisteminin ikilikler içermesi üzerine eğitim alanında reform yapılmak istenmiştir. Ayrıca yabancı okulların denetlenmemesi nedeniyle eğitim faaliyetinde bulunan bütün kurumların tek çatı altında toplanması istenmiştir (Ertan vd., 2018: 188). Cumhuriyet dönemine uygun eğitim yapısının sağlanması (Arı, 2002: 185) adına, Büyük Millet Meclisi'nin 1 Mart 1924 tarihinde yapılan ikinci oturum açılışında (Kocatürk, 2000: 409) görüşmeler yapılmıştır. Bu görüşmelerde Tevhid-i Tedrisat Kanunu haricinde konularda görüşülmüştür.

Gazi Mustafa Kemal'in 1 Mart tarihinde oturumda yaptığı açılış konuşmasında, üç ana başlık üzerinde durmuş ve bu başıkları Nutuk adıı eserinde aşağıdaki şekilde ifade etmiştir:

4. "Millet, Cumhuriyetin bütün saldırılardan kesin ve ebedi olarak korunmasını istemektedir. Milletin isteği, Cumhuriyet'in denenmiş ve olumlu sonuçları görülmüş olan bütün esaslara bir an önce ve tam olarak dayandırılması şeklinde ifade edilebilir."

5. "Millet kamuoyunda tespit edilen eğitim ve öğretimin birleştirilmesi ilkesinin bir an önce uygulanmasını gerekli görüyoruz"

6. "Müslümanlığın yüzyıllardan beri yapılageldiği üzere bir siyaset vasıtası olarak kullanılmaktan kurtarılmasının ve yüceltilmesinin şart olduğu gerçeğini de görmüş bulunuyoruz"(Atatürk, 2009: 574).

Bir gün sonra, 2 Mart 1924 tarihinde Halk Partisinin grup toplantısında Gazi Mustafa Kemal'in önerdiği bu başlıklar görüşülmüş ve parti milletvekilleri tarafından bir gün sonra 3 Mart 1924'te Meclise (Arı, 2002: 187) sunulmuştur. Meclis başkanlığına sunulan üç önerge Nutuk adlı eserde ifade edildiği gibi şu şekildedir:

4. "Osmanlı hanedan ailesinin sürgün edilmesi ve Halifeliğin kaldırılması konusunda, Urfa Mebusu Şeyh Saffet Efendi ve elli milletvekilinin kanun teklifi."

5. Dönemin Genelkurmay Başkanlı̆̆ı görevini yapmakta olan Erkan-ı Harbiye Vekaleti ile dönemin Diyanet İşleri Başkanlığı ve Vakıflar Müdürlüğü görevini yapmakta olan Şer-iye ve Evkaf 
Vekaleti'nin kaldırıması ile ilgili Siirt milletvekili Halil Hulki Efendi ve elli milletvekilinin kanun teklifi."

6. "Manisa milletvekili Vasıf Bey ve elli arkadaşının, eğitim ve öğretimin birleştirilmesi ve tek çatı altında toplanması konusu ile ilgili kanun teklifi" (Atatürk, 2009: 574).

Bazı milletvekilleri itiraz etse de kabul edilen bu maddeler ile birlikte Tevhid-i Tedrisat Kanunu da kabul edilerek, ülke içerisinde bulunan bütün eğitim faaliyeti yürüten kurumlar Maarif Vekaletine (Ertan vd., 2018: 188) bağlanmıştır. 22 Mart 1926 tarihinde Meclis'te kabul edilen Maarif Teşkilatı Hakkında Kanun (Kocatürk, 2000: 452) ile Tevhid-i Tedrisat Kanununa eklemeler yapılmış ve devletin izni olmadan okul açılması önlenmiştir (Ertan vd., 2018: 188).

\section{HARF INKILABI}

Türkler İslamiyeti kabul etmeden önce Göktürk ve Uygur alfabelerini kullanıyorlarken İslamiyet ile birlikte Arap Alfabesini kullanmaya başlamışlardır (Avcı, 2013: 44). Osmanlı Devleti zamanında da kullanımına devam edilen Arap harfleri Cumhuriyet'in ilanı ile birlikte tartışmaları da beraberinde getirmiştir. Bazı kaynaklarda Harf İnkılabı ile ilgili yenilik düşüncesinin Tanzimat Fermanı'na (Acar, 2012: 22) kadar dayandığı belirtilmektedir. Gazi Mustafa Kemal, Birinci Dünya Savaşı́nın sona ermesinin hemen ardından Kurtuluş Savaşı öncesinde Erzurum Kongresi esnasında, yol arkadaşlarından olan Mazhar Müfit Kansu'ya Latin Harfleri konusunu not ettirdiği (Ertan vd., 2018: 189) kesin olmamakla birlikte bazı yayınlarda ifade edilmektedir.

Gazi Mustafa Kemal, Kurtuluş Savaşı́nın sona ermesiyle birlikte başlatmış olduğu yenilik hareketlerinde, harf devrimi konusunu da dillendirmiş ve toplumun tepkisini merak etmiş, tartışmaları yakından izlemiştir (inan, 2018: 183). Cumhuriyet döneminde harf inkılabı adına yapılan ilk çalışmalar İzmir iktisad Kongresi'ne dayanmaktadır. Bu kongrede yapılan görüşmeler de sert tartışmalar olmuş ancak sonunda kongre başkanı Kazım Karabekir Paşa'nın (Turan, 2018: 388) kabul etmemesiyle Latin harflerine geçiş talebi kabul edilmemiştir. 24 Şubat 1924 yılında İzmir milletvekili Şükrü Saraçoğlu Arap alfabesinin kaldırımasını teklif etse de mecliste çıkan tartışmalar sonucunda tekrar kabul edilmemiştir. Mustafa Kemal bu konunun halk arasında kabul görmediğini (Turan, 2018: 388) düşünerek bu dönemde çıkarılması taraftarı olmamışır.

Harf Devrimi açısından ilk teşebbüslerin ardında geçen süre sonrasında, ilk adım 20 Mayıs 1928 yılında uluslararası rakamların kullanımına başlanması(Kocatürk, 2000: 478) ile atılmış oldu. Bu tarihten yalnızca üç gün sonra ise Cumhurbaşkanı Mustafa Kemal'in talimatı ile Milli Eğitim Bakanlığı bünyesinde "Dil Komisyonu" kurulmasına (Turan, 2018: 388) karar verilmiştir. Üç ay süren bu komisyonun çalışmalarına bazı zamanlarda Cumhurbaşkanı da iştirak etmiştir (İnan, 2018: 183).

Yapılan çalışmalar sonunda, 1 Kasım 1928 yılında Cumhurbaşkanı Gazi Mustafa Kemal Türkiye Büyük Millet Meclisi'nin açוlışında, yeni Latin alfabesinin kabulünün önemine binaen konuşma (Ertan vd., 2018: 190) yaptı. Bu konuşmanın akabinde Dil Komisyonunun hazırlamış olduğu kanun teklifi kabul edildi. 3 Kasım 1928'de kanun 
yürürlüğe girerek resmi gazetede yayınlandı (İnan, 2018: 185). Böylece Türklerin İslam dinini kabulünden bu yana kullanmakta olduğu Arap harfleri bırakılarak Latin harflerine geçilmiştir.

\section{TEVHID-i TEDRISAT KANUNU VE HARF INKILABI ILE ILGILI BAZI KARIKATÜRLER}

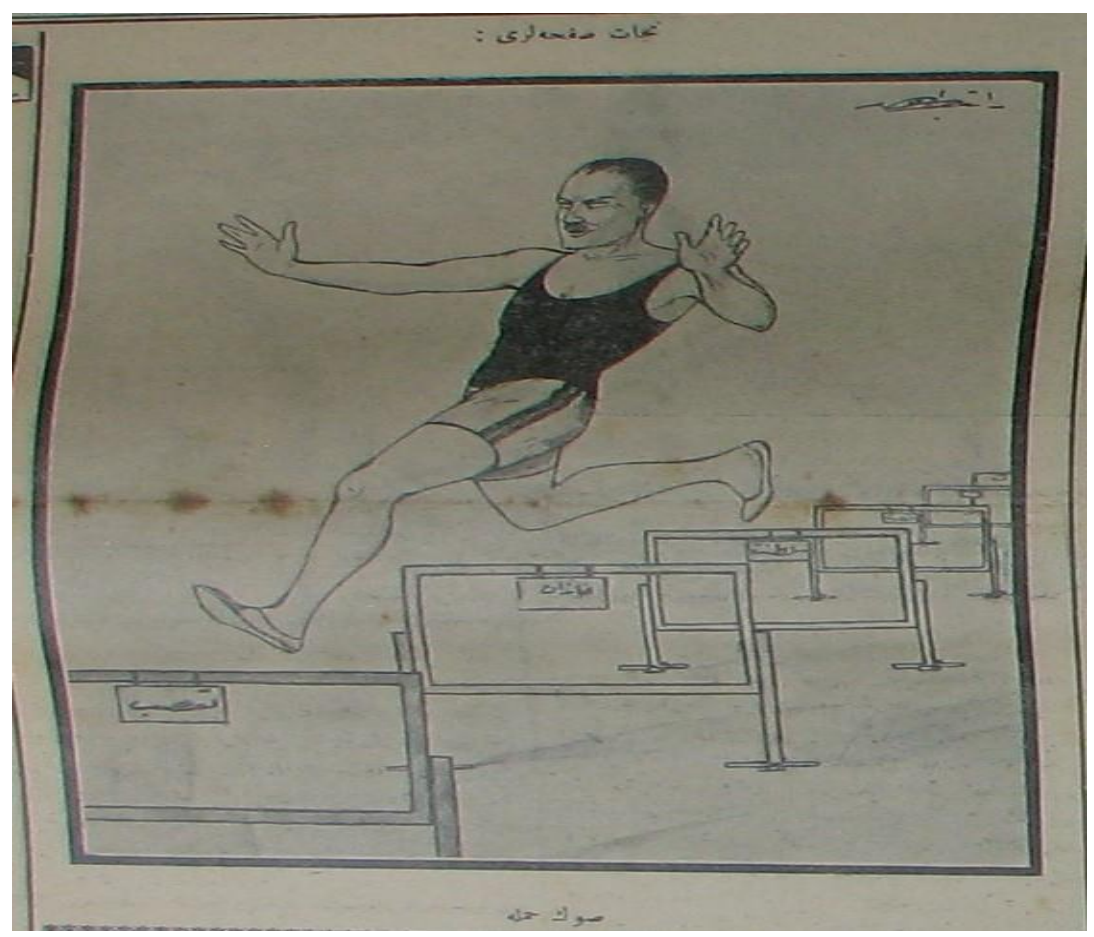

Karikatür-1 (Tahir, 1924)

\section{Karikatürün Çevirisi}

Üst yazı: Necat(kurtuluş) zamanı.

Dördüncü engelden itibaren sırasıyla: Saltanat, Hanedan ve Taassub(bağnazlık).

Alt yazı: Son hamle. 


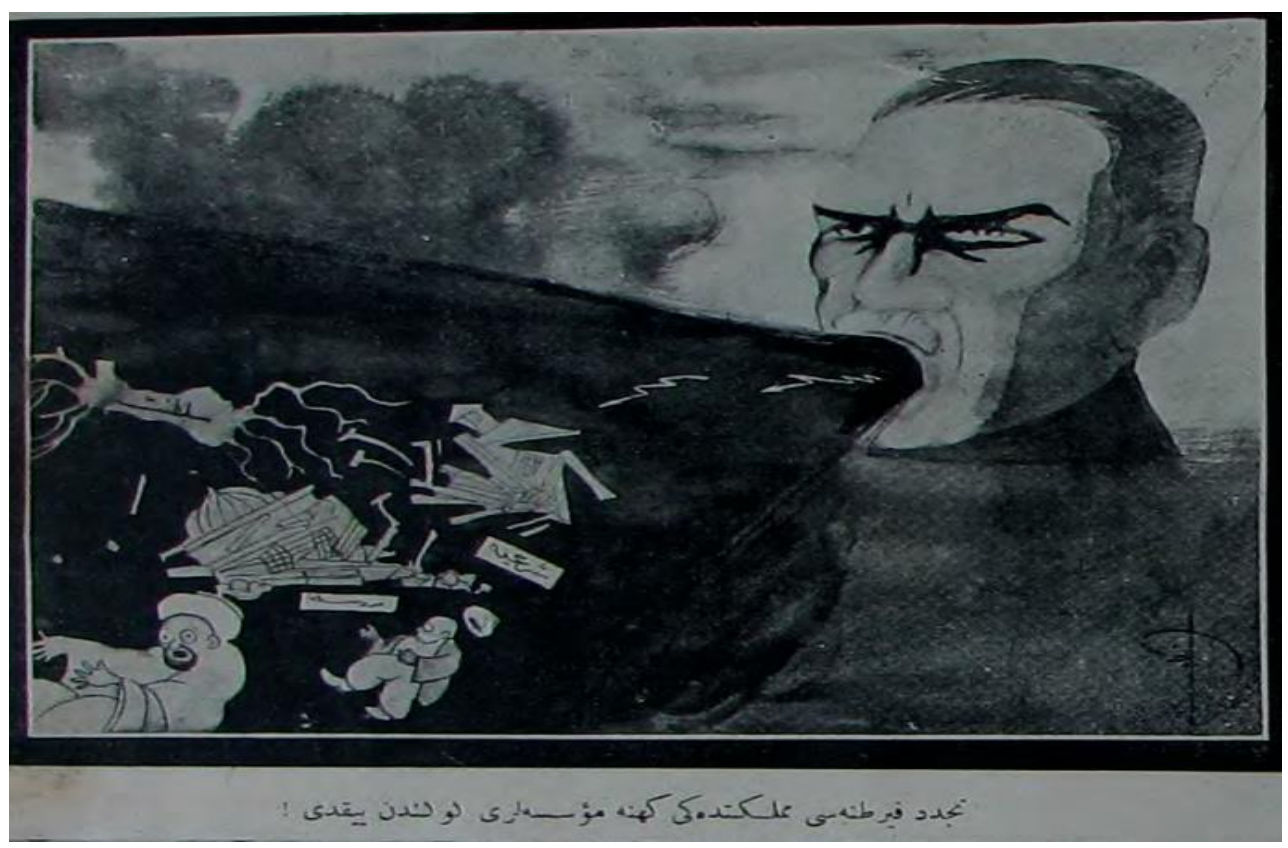

Karikatür-2 (Gökçe, 1924)

\section{Karikatürün Çevirisi}

Alt yazı: Tecdid(yenilenme) fırtınası memlekette ki köhne müesseseleri kökünden yıktı.

\section{Karikatür 1 ve 2 hakkında}

Karikatür 1 çizeri Ratib Tahir, Cumhuriyet'in kurulması sonrasında yapılan yeniliklerden bazılarını engel olarak çizerek, Mustafa Kemal’in her atladığı engel sonrasında yarışı başarıyla tamamlayacağını ifade etmeye çalışmıştır. Son hamlesi ise taassub yani bağnazlıktır. Karikatür 2'de ise çizer Mustafa Kemal'in ağzından bir fırtına resmederek yenilik hareketlerini betimlemiştir. Fırtınanın içerisinde yıkık medrese ve sarıklı cübbeli hocalar yer almaktadır. Fırtınanın içerisinde Osmanlıca olarak şeriat, saltanat ve medrese yazılmış. Gazi Mustafa Kemal sayesinde fırtınanın bu müesseseleri hortum gibi çektiği resmedilmiştir. 3 Mart 1924 tarihinde Meclise sunulan ve kabul edilen maddeler; Osmanlı Hanedan ailesinin sürgün edilmesi ve hilafetin kaldırılması, Erkan-ı Harbiye Vekaleti ile Şer-iye ve Evkaf Vekaleti'nin kaldırılması ve eğitim öğretimin tek çatı altında toplanmasıdır. Bu kanunlardan sonra yayınlanan iki karikatürde herhangi bir eleştiri içermemekte olup yapılan yeniliklerin yanında olunduğu ve hükümete destek verildiği görülmektedir. 


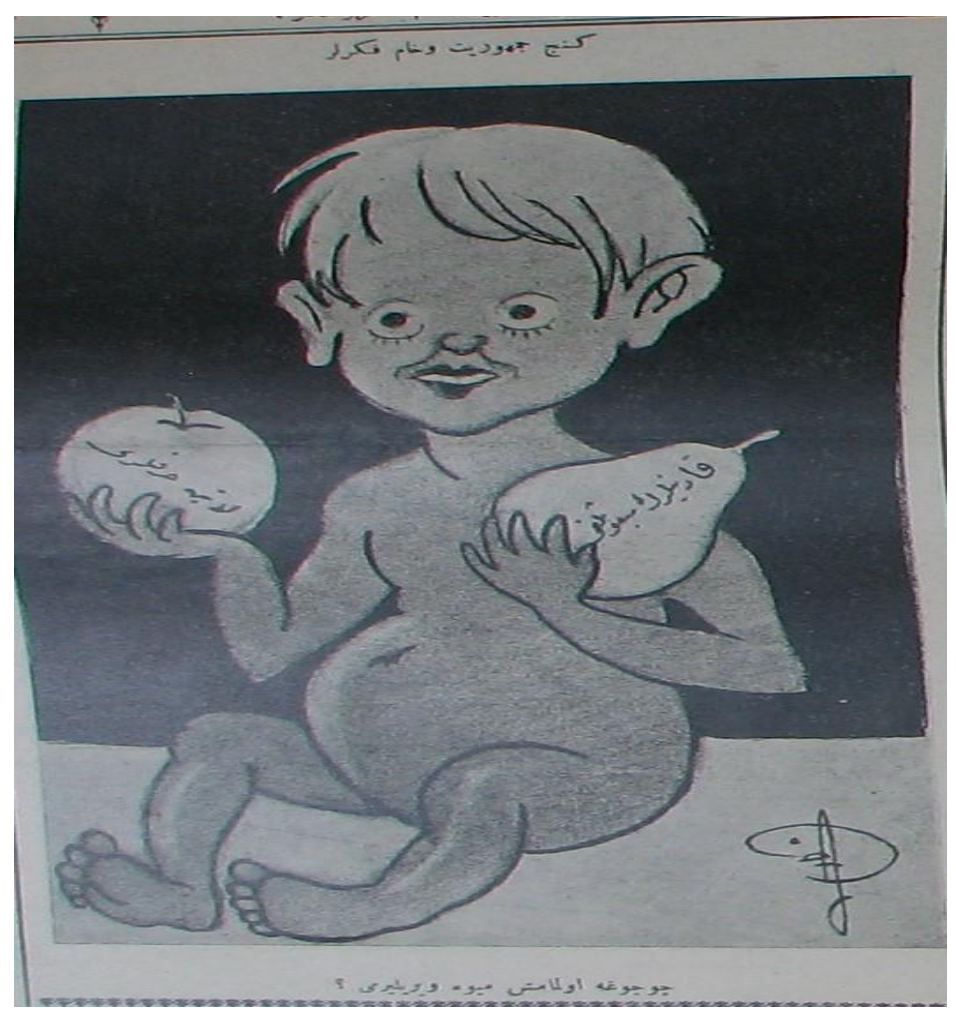

Karikatür-3 (Tahir, 1924)

\section{Karikatürün Çevirisi}

Üst yazı: Genç Cumhuriyet ve Ham Fikirler

Çocuğun elindeki elmada: Latin Harfleri

Armutta: Kadınların Mebusluğu

Alt yazı: Çocuğa olmamış meyve verilir mi?

\section{Karikatür-3 Hakkında}

Dönemin mizah yayınları incelendiğinde en eleştirel yayınların, harf inkılabı ile kadınların milletvekilliği meseleleri üzerine olduğu görülmektedir. Gazi Mustafa Kemal bu inkılapların halk tarafından tartışılmasını sağlamış ve bu yönde yapılan çalışmalar ile kamuoyunu hazırlamıştır. Bu dönemde bu Harf inkılabına halkın ve basının kabulünün söz konusu olmadığını fark etmiştir(Turan, 2018: 387). Karikatür 3 'te çizildiği gibi, çocuğun elindeki elmanın üzerinde 'latin harfleri' ve armutun üzerinde 'kadınların mebusluğu' yazılmıştır. 20 Mart 1924'te çizilen bu karikatürde, “Çocuğa olmamış meyve verilir mi?" sorusundan da anlaşılmaktadır ki, Türkiye halkı ve karikatüristler bu iki reformun daha olgunlaşmamış olduğunu düşünmektedirler. 


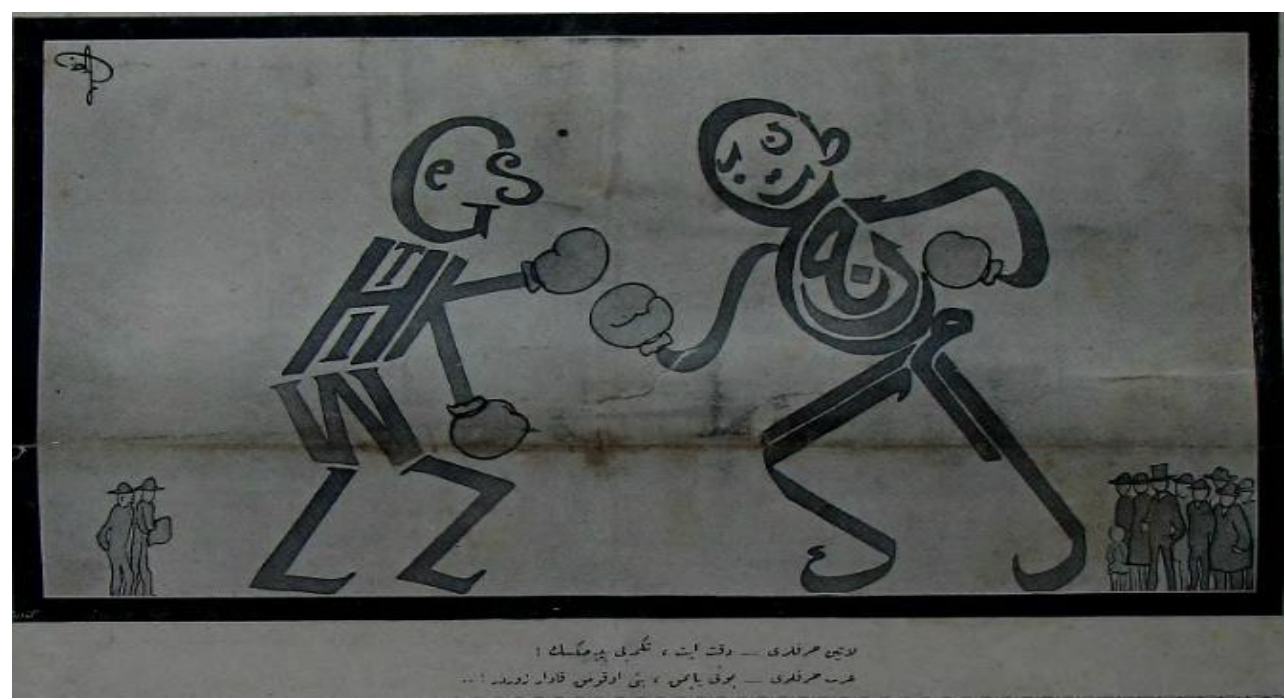

Karikatür-4 (Gökçe, 1926)

\section{Karikatürün Çevirisi}

Latin Harfleri: Dikkat et tekmeyi yiyeceksin!

Arap Harfleri: Bunu yapmak beni okumak kadar zor!...

\section{Karikatür-4 Hakkında}

Latin harfleri ile Arap harflerini birbiri ile boks maçında çizen Ramiz Gökçe, Arap harflerini okumanın zorluğunu halka göstermeye çalışmaktadır. Bu karikatür daha Harf inkılabının kabul edilmediği zamanlarda yayınlanmıştır. Karikatürün en dikkat çeken yanı ise Latin harflerinin ve Arap Harflerinin arkasında bulunan insan kalabalığıdır. Latin harflerinin arkasında 2 kişi dururken, Arap harflerinin arkasında çokça insan çizilmiştir. Bu görselden 1926 yılında halk tarafından Latin harflerinin tam olarak benimsenmediği ve Harf İnkılabının kabul görmediği izlenimi verilmektedir. Akbaba dergisi ve karikatür çizeri Ramiz Gökçe halka Arap harflerini okumanın zorluğunu göstermeye çalışmakta olup, derginin yayınlarının Harf inkılabından taraf tutumu net bir şekilde görülmektedir. 


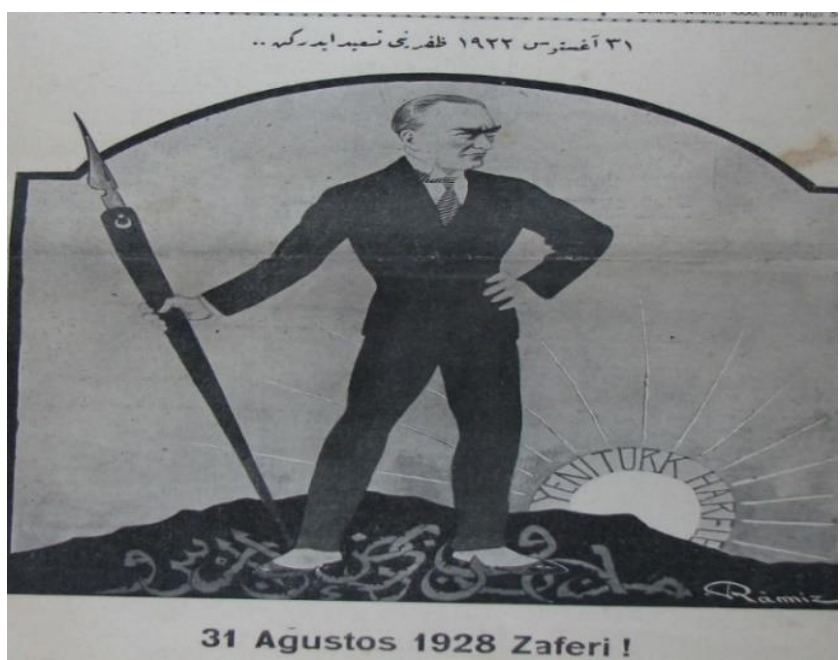

Karikatür-5 (Gökçe, 1928)

\section{Karikatürün Çevirisi}

Üst yazı: 31 Ağustos Zafer Bayramını tasvir ederken.

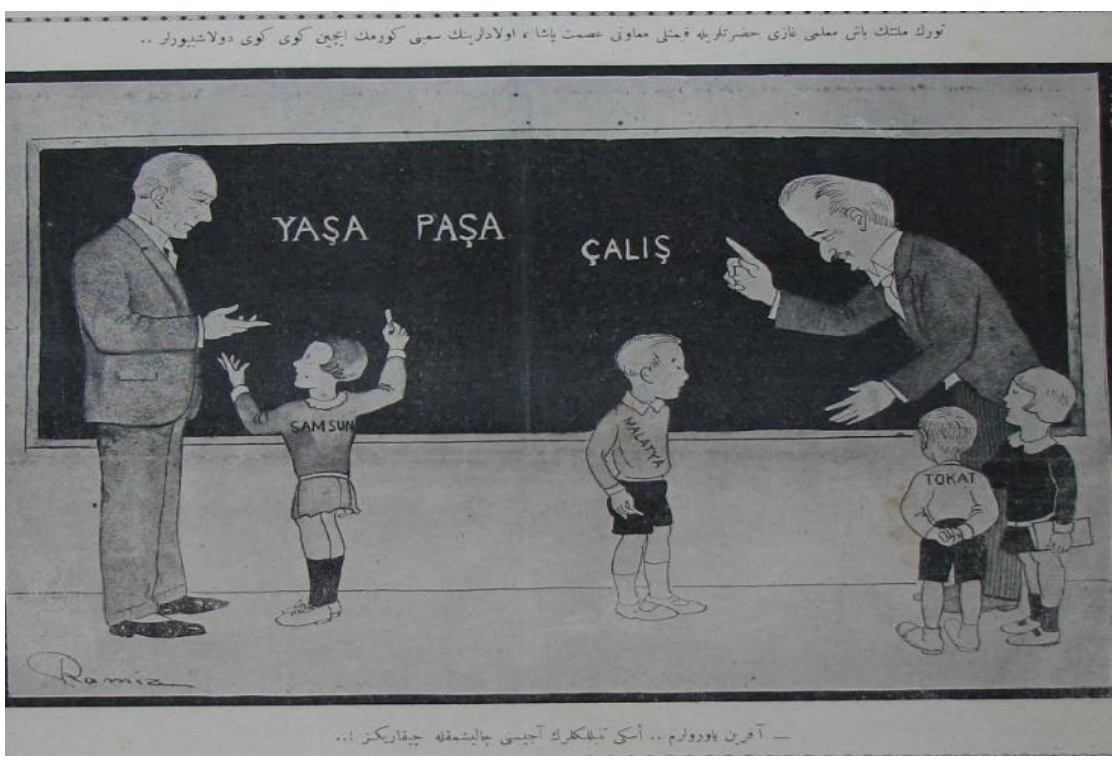

Karikatür-6 (Gökçe, 1928)

\section{Karikatürün Çevirisi}

Üst Yazı: Türk Milletinin başmuallimi Gazi hazretleriyle kıymetli muavini İsmet paşa, evlatlarının saini görmek için köy köy dolaşıyorlar...

Alt Yazı: Aferin yavrularım... Eski Tembelliklerin acısını çalışmakla çıkarınız. 


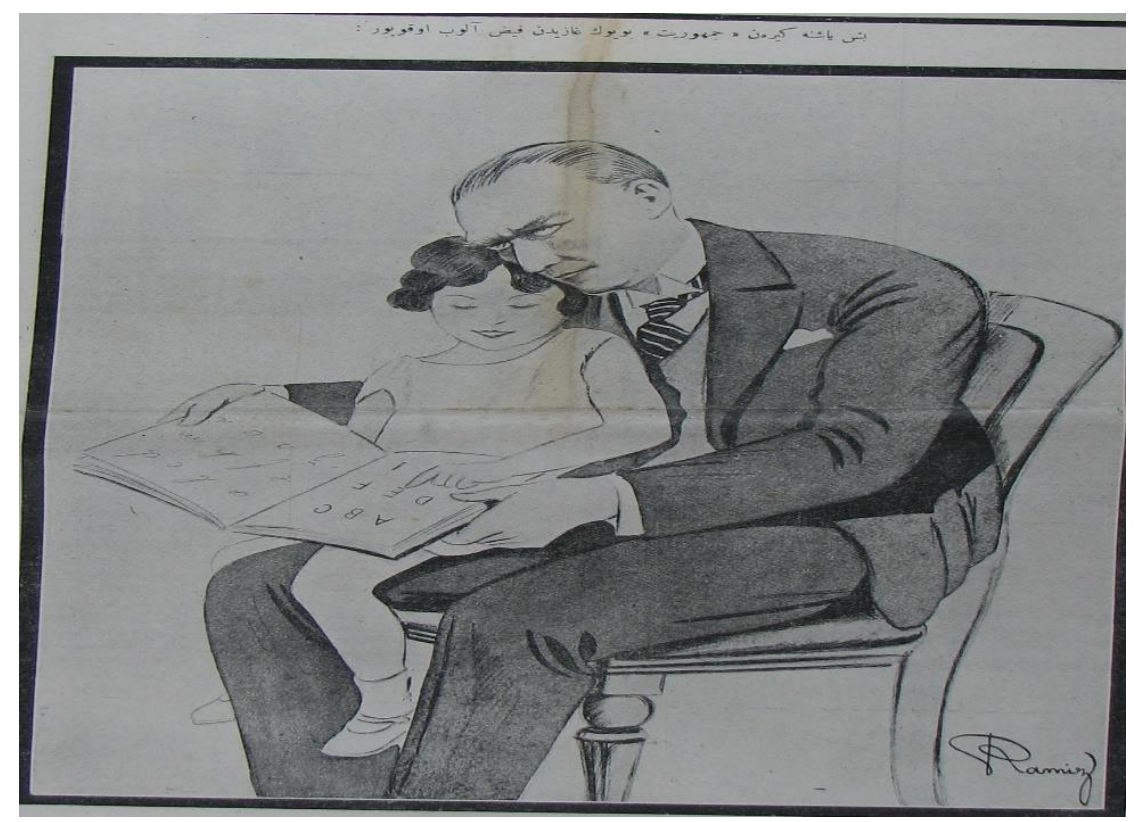

Karikatür-7 (Gökçe, 1928)

\section{Karikatürün Çevirisi}

Üst yazı: Beş yaşına giren "Cumhuriyet" Büyük Gaziden Feyz alıp okuyor.

\section{Karikatür-5, 6 ve 7 Hakkında}

Karikatür 5'te, Gazi Mustafa Kemal eski Arap harflerinin üzerine basarak sağ elinde kalem tutmaktadır. Karikatürün arka tarafından doğan güneşte yeni Türk harfleri yazmaktadır. Kurtuluş Savaşı sonrası kutlanan 31 Ağustos Zafer Bayramı, Arap harflerinin bırakılarak Latin harflerinin kabul edilmesi bir zafer gibi gösterilmektedir. Bu karikatür de Latin harflerinin kabulü düşman işgalinden kurtarılmış Cumhuriyet gibi gösterilmektedir.

Karikatür 6 ve 7'de ise Latin harflerine geçişin önemini göstermesi bakımından Cumhurbaşkanı ve Başbakan ülke genelinde bazı okullarda öğrencilere Latin harflerinin eğitim verilerek gösterilmektedir. 


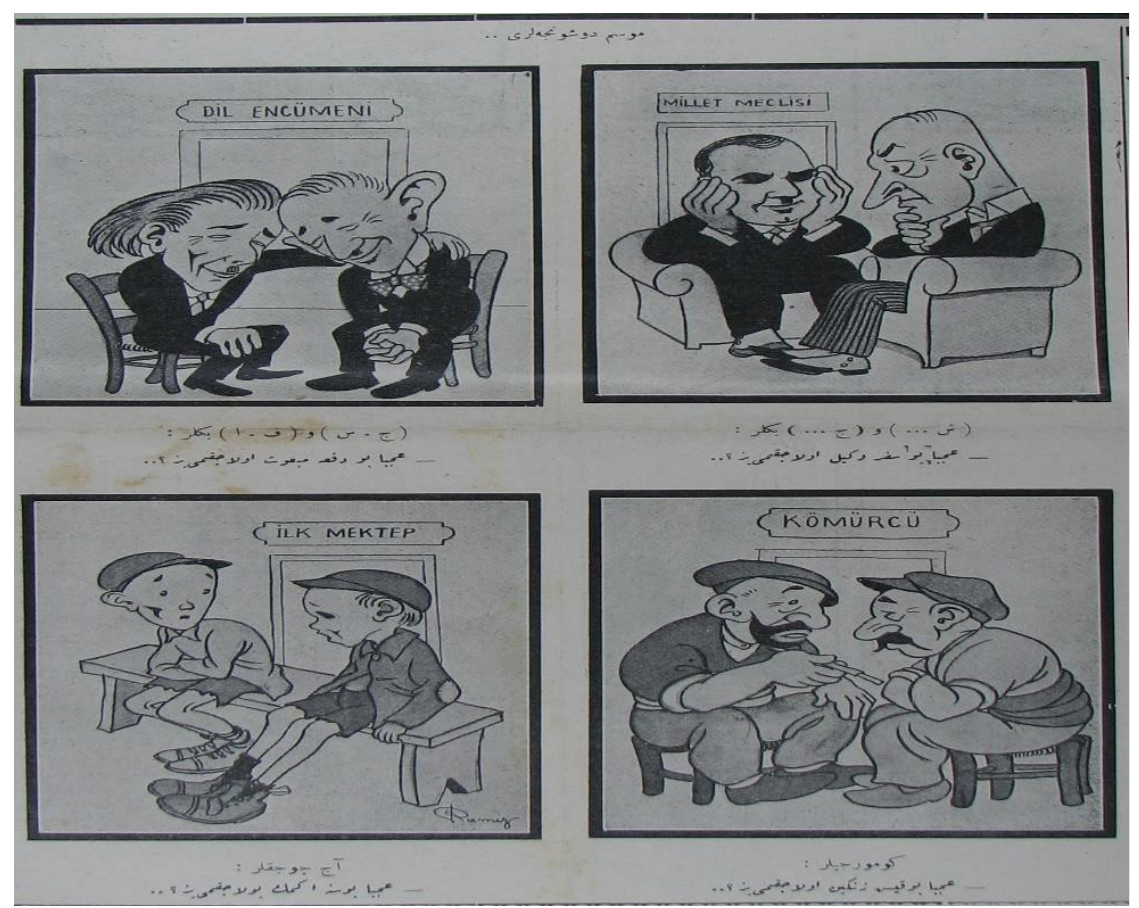

Karikatür-8 (Gökçe, 1928)

\section{Karikatürün Çevirisi}

Üst yazı: Mevsim düşünceleri.

Dil Encümeni karikatürünün alt yazısı:

(Arapça Cim ve Sin harfleri) ve (Elif ve fe Harfleri) Beyler:

-“Acaba bu defa mebus olacak mıyız?"

Millet Meclisi karikatürünün alt yazısı:

(Arapça Şın harfi) ve (Arapça Cim harfi) Beyler:

-“Acaba bu sefer vekil olacak mıyız?"

Illk Mektep karikatürünün alt yazısı:

Aç çocuklar: "Acaba bu sene ekmek bulacak mıyız?"

Kömürcü karikatürünün alt yazısı:

Kömürcüler: “Acaba bu kış zengin olacak mıyız?” 


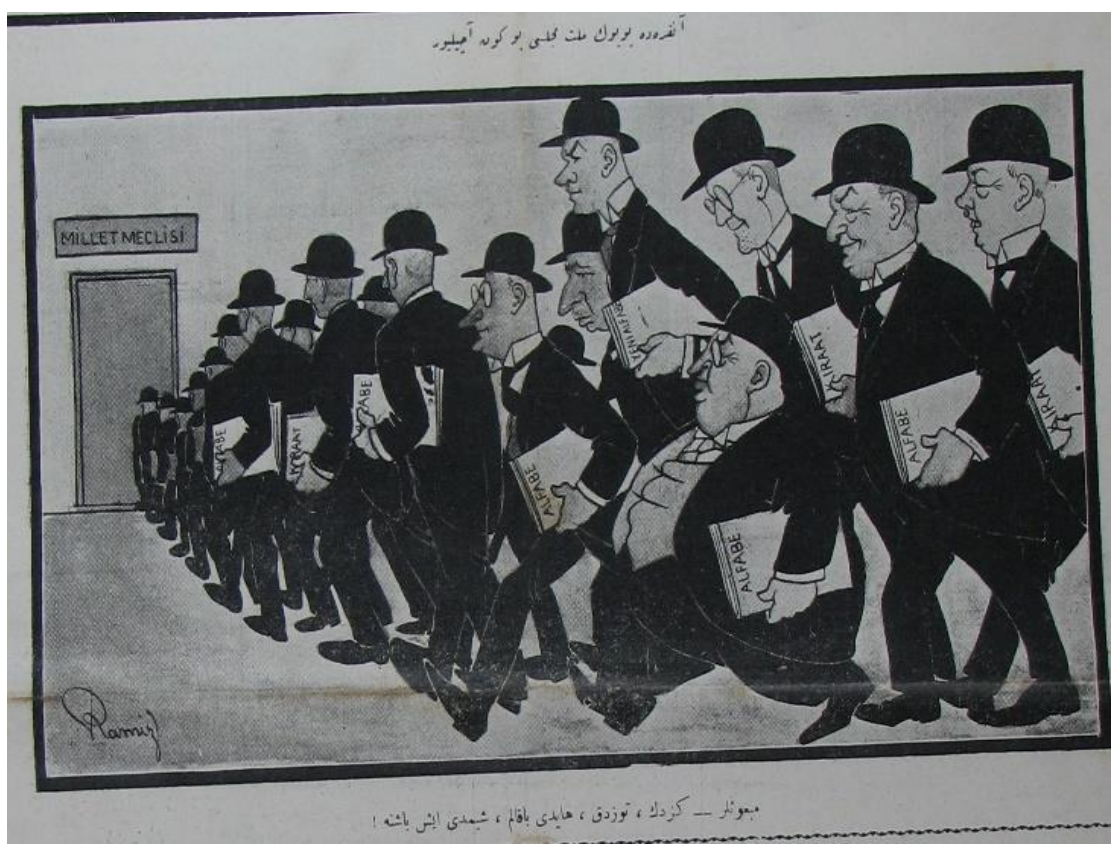

Karikatür-9 (Gökçe, 1928)

\section{Karikatürün Çevirisi}

Üst yazı: Ankara Büyük Millet Meclisi bugün açılıyor.

Alt yazı: Mebuslar - "Gezdik, tozduk, haydi bakalım, şimdi iş başına!”

\section{Karikatür-8 ve 9 Hakkında}

8 numaralı karikatürde harf inkılabının etkilediği bazı kesimler bulunmakta olup bu kesimler toplumun halini gözler önüne sermektedir. Harf inkılabının bir nevi öncüsü sayılan Dil Encümenindeki kişiler inkılap sonrası milletvekilliği beklemektedir. Millet meclisinde bulunan milletvekilleri ise harf inkılabının başarıyla Meclisten geçirilmesi ile birlikte tekrar milletvekilliği beklemektedirler. Asıl önemli olan ise, okullarda eğitim gören öğrencilerin "ekmek bulabilecek miyiz" sözü ile kömürcülerin "zengin olabilecek miyiz" düşünceleridir. Karikatür çizeri Ramiz Gökçe, harf inkılabını yapanların mevki peşinde bulunmalarını yermiş, halkın açlıktan kurtulma ve para kazanma isteğini konu edinmiştir.

9 numaralı karikatürde, küçükte olsa bir hiciv söz konusudur. Çünkü Millet Meclisi açılırken bütün milletvekillerinin tek düşüncesi vardır, "Harf İnkılabı". Ancak halkın asıl beklentisi mali konular olduğu Akbaba Dergisinin bu sayısında görülmektedir. 


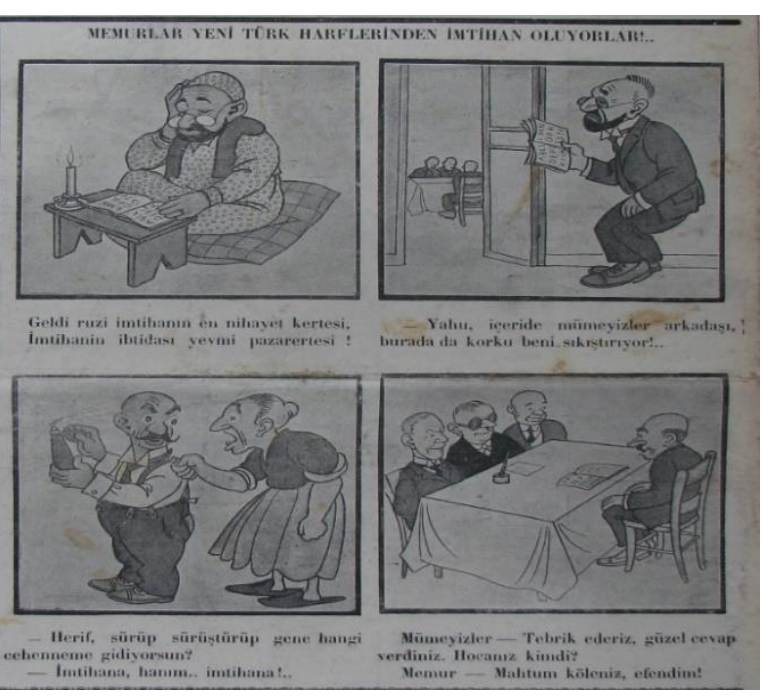

Karikatür-10 (Karikatür, 1928)

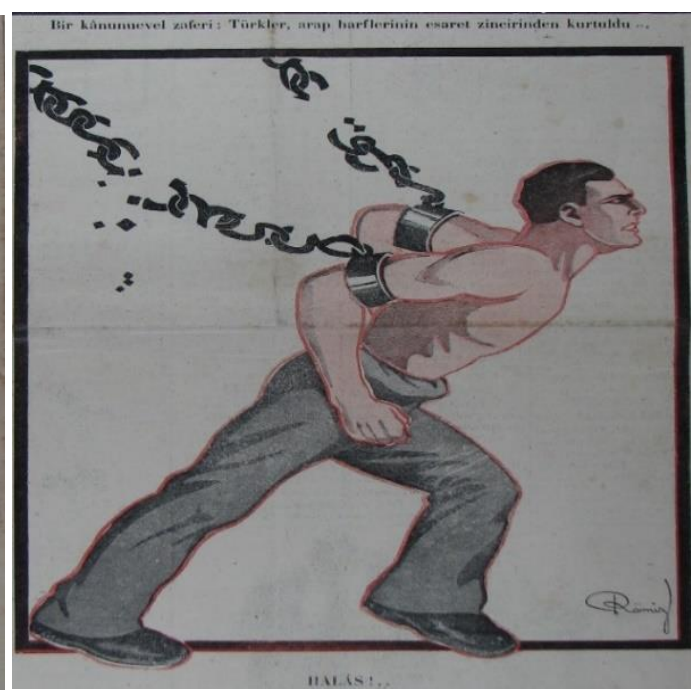

Karikatür-11 (Gökçe, 1928)

\section{Karikatür-10 ve 11 Hakkında}

10 ve 11 numaralı karikatürlerin özelliği Latin harfleriyle yazılmasıdır. 3 Kasım 1928 yılında yürürlüğe giren (İnan, 2018, s. 185) Latin harfleri ile gazete ve dergilerin yayınlarına başladığı görülmektedir. 10 numaralı karikatürde daha Kasım ayında olunmasına rağmen memurların sınava tabii tutulduğu karikatürde görülmektedir. 11 numaralı karikatürde ise zincirle bağlanmış kişi zincirlerinden kurtulmaktadır. Buradaki zincir Arap harfleridir. Karikatürün altında ise halas yani bitti yazmaktadır. Bu karikatür ile Akbaba'nın Latin harfleri konusundaki bakışı net olarak görülmektedir. 


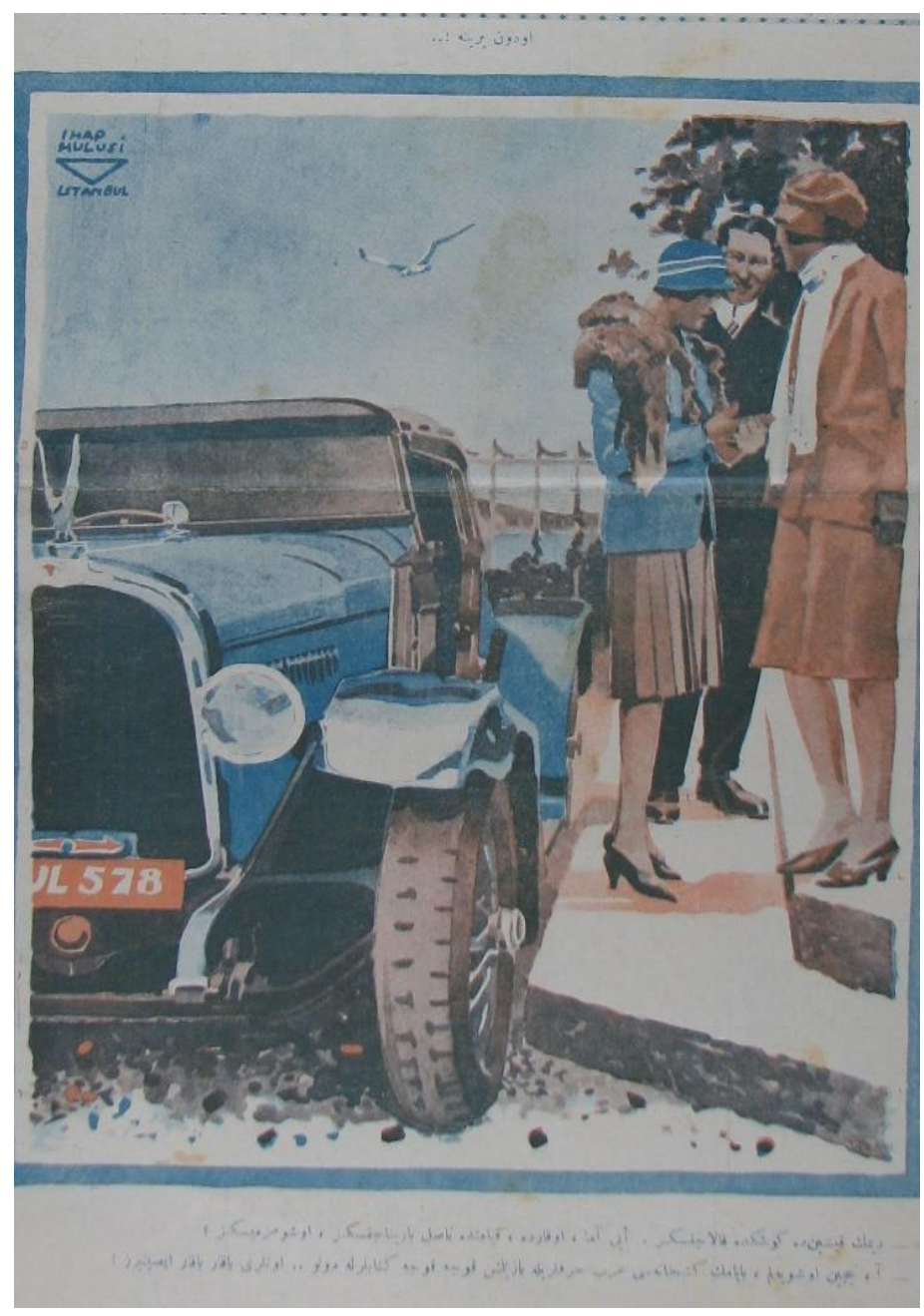

Karikatür-12 (Görey, 1928)

\section{Karikatürün Çevirisi}

Üst yazı: Odun Yerine!...

Alt yazı: “Demek kışında köşkte kalacaksınız. İyi ama o karda, kıyamette nasıl barınacaksınız, üşümez misiniz?”

“Aa, niçin üşüyelim, babamın kütüphanesi Arap harfleriyle yazılmış koca koca kitaplarla dolu... Onları yakar yakar ısınırız!"

\section{Karikatür-12 Hakkında}

Bu karikatürü kullanılmasının nedeni karikatürün alt yazısında bulunan konuşmalardır. Arap harflerini bırakıp Latin harflerine geçiş o kadar hızlı benimsenmiş ki Arap harfleriyle yazılmış kitapların önemi düşünülmeden sadece ısınmak için bile yakılması düşünülmektedir. Karikatür çizeri İhap Hulusi bu karikatürle dönemin bir kesim halkının Arap harflerine bakış açısını net bir şekilde bizlere göstermektedir. 


\section{SONUÇ}

Karikatürler yaşanılan dönemin mizah ile birlikte eleştirel kimliklerini ortaya koyan önemli argümanlardır. Günümüz siyasi ve sosyal hayatının aksaklıklarını konu edinerek halka yayınlarda bulunan bu basılı yayın organlarının incelenmesi, bir nevi dönemin röntgenini çekmek demektir. Mizah ve karikatür dergilerinin Erken Cumhuriyet döneminde edindiği misyon, dönemin hükümetinin ve halkının zihinsel yapısını ortaya koyması bakımından oldukça önemlidir. Kurtuluş Savaşı́nın başarı ile bitmesi sonrasında iktidara gelen hükümetin, kökten değişim fikri ile yenilik ve reformlara yönelecek olması, her şartta yanında bulunan Milli İradenin onayı ile mümkün olabilirdi. 1.Dünya Savaşı ve Kurtuluş Savaşı'nı yaşamış yorgun halkın yüzyıllardır alışılagelmiş düzeninde yaşanacak değişimlere karşı takınacakları tavır yeni kurulacak devletin önünde ciddi bir engel olabilirdi.

Birinci Dünya Savaşı sonunda savaşın kaybedilmesi ve İtilaf Devletlerinin Anadolu'yu işgali ile birlikte, Osmanlı toplumunda hüzünlü ve umutsuz bir dönem başlamıştır. Uzun ve meşakkatli yolun başlangıcı olan 19 Mayıs 1919 tarihinde Milli Mücadele'nin ilk adımlarının atılması ile birlikte halkta İtilaf Devletlerinin işgalinden kurtulma ümidi yeniden yeşermiştir. Bu ortamda Anadolu’nun her yerine haberin ulaşması ve halkın bilinçlendirilmesi, dönemin neredeyse tek haber kaynağı olan basılı yayınlar vasıtasıyla yapılabilmekteydi. Halkın üzerindeki etkisi düşünüldüğünde basılı yayınların önemi büyüktür. Aynı şekilde dönemin okuryazarlığının düşük seviyede olduğu iddiaları da düşünüldüğünde, basılı yayınlarda ki görsellerin önemi daha da artmaktadır. Bu nedenle karikatür yazar ve çizerlerine büyük sorumluluk düşmekteydi.

Milli Mücadele'nin başarı ile sonuçlanması ile birlikte ülke genelinde ciddi yenilik ve reform hareketlerine başlanmıştır. Eğitim, hukuk, ekonomik ve gündelik yaşamı etkileyen birçok inkılap hayata geçirilmiştir. Düşük okuryazarlık oranı dikkate alındığında, halkın yazılı basından ciddi şekilde etkilendiği düşünülmektedir. Bu çerçevede makalenin konusu olan Tevhid-i Tedrisat Kanunu ve Harf İnkılabı'nın dönemin mizah dergi ve gazetelerinde nasıl işlendiği araştırılmış ve bu çerçevede Zümrüd-ü Anka ve Akbaba dergileri incelenmiştir. Günümüzde hala halk arasında veya siyasi mecraalarda tartışmalara neden olan bazı İnkılapların, Erken Cumhuriyet dönemi kamuoyunda nasıl bir etki yarattığını mizah ve karikatür dergileri vasıtasıyla öğrenmemiz mümkündür. Cumhuriyet döneminin önemli inkılaplarından olan Tevhid-i Tedrisat Kanunu ve Harf İnkılabı, halk üzerinde uzun süre kamuoyu oluşturulmaya çalışılmış birer yeniliktir. Bizzat Gazi Mustafa Kemal'in daha olgunlaşma döneminde olan inkılapları, halk ile birlikte bulunduğu her ortamda onlara sorduğu ve halkın nabzını tuttuğu bilinmektedir. Türkiye Cumhuriyeti'nin kurulduğu ilk yıllarda, halkın birlikteliğinin sağlanmadığı her konunun Milli İradenin birlikteliğini zedeleyeceği düşünülmektedir.

Tevhid-i Tedrisat Kanunu ve Harf İnkılabı çerçevesinde Zümrüd-ü Anka ve Akbaba mizah dergilerinde dönemin hükümetine karşı kayda değer eleştiride bulunulmadığı görülmektedir(Cantek ve Gönenç, 2017: 13). Bu durumun iki nedeni vardır; birincisi, halkın ve basının İtilaf devletlerine ve İstanbul Hükümetine karşı Ankara hükümetini desteklemesidir. İkinci neden ise Milli Mücadelenin başarı ile sonuçlanmasıyla birlikte halkta ve basında sevinç dönemi yaşanıyor olmasıdır. Akbaba gazetesi dönemin mizah dergileri arasında amiral gemisi olarak görülmektedir. Akbaba dergisi nezdinde konular incelendiğinde, Tevhid-i Tedrisat Kanunu ve Harf İnkılabı'na ciddi 
bir hiciv veya eleştiri yöneltilmediği görülmektedir. Bu durumun ana nedeni Akbaba dergisinin yayın hayatı boyunca siyasi iktidarla yakın ilişki içerisinde olmasıdır. Bu yakınlık ile birlikte hükümete karşı muhalif olanları eleştirmesi doğrultusunda maddi teşvik aldığı dahi iddia edilmiştir (Cantek ve Gönenç, 2017: 12).

Zümrüd-ü Anka dergisinin ise 2 yıl süren yayın hayatı süresince yapmış olduğu yayınlar incelendiğinde, Tevhid-i Tedrisat Kanunu ve Harf İnkılabı hakkında bilgi ve karikatür bulmak zordur. Dergide, Tevhid-i Tedrisat kanunu hakkında 1. karikatürde konu edinilen yayını görmekteyiz. Bu karikatürde herhangi bir eleştirinin söz konusu olmadığı görülmektedir. Ancak 3. Karikatürde yukarıda da bahsettiğimiz üzere küçük çocuğun elinde elma ve armut vardır. Elmada "Latin harfleri" armutta ise "Kadınların mebusluğu" yazmaktadır. Üst başlıkta ise "Genç Cumhuriyet ve Ham Fikirler" yazmaktadır. Bu karikatürde Zümrüd-ü Anka gazetesi çizeri Ratib Tahir, Latin harflerinin kabulünün yeni ve ham olduğu düşüncesine sahiptir. Bu karikatür de ise küçük bir eleştiri olsa da diğer yönüyle daha olgunlaşmamış bir meyvenin yani "Latin Harfi ile Kadınların Mebusluğu" gibi inkılapların olgunlaşması istenmektedir.

Günümüzde hala tartışma konusu olan inkılaplar arasında, Tevhid-i Tedrisat Kanunu ve Harf İnkılabı seçilerek dönemin karikatür çizerlerinin ve basılı yayın yapan kurumların Cumhuriyet'in başlangıç dönemlerinde yapılan inkılaplara karşı herhangi bir eleştirilerinin bulunup-bulunmadığı konusu işlenmeye çalışılmıştır. Günümüzde eleştirilerin ve hicivlerin kaynağı olarak görülen karikatürler, okur-yazar oranının az olduğu iddia edilen bir dönemde basılı yayınların halkın üzerindeki etkisi dikkate alınarak Zümrüd-ü Anka ve Akbaba dergileri incelenmiş ve kayda değer ciddi bir eleştiriye rastlanmamıştır.

Yenilik ve reform hareketleri devletler için sancilı geçebilecek dönemlerdir. Bu süreçler ihtiyaç duyularak yapılmasına rağmen, dönemin şartları düşünülmeden yıllar sonrasında eleştirilmesi, tartışıması mümkündür. Erken Cumhuriyet döneminde basın, yaşanılan onca badirenin ardından devletinin yanında durmuş, yapılan reform ve yeniliklerin halka anlatımında önemli bir görev üstlenmiştir. Yapılan yenilik ve reformlara karşı olumlu tavır sadece basılı yayın ve gazetelerin sayfalarına yansımamış, aynı zamanda mizah ve karikatür çizerlerini de etkilemiştir (Yetim \& Akkoyunlu, 2017: 96).

\section{ETiK}

Bu makalede dergi yazım kurallarına, yayın ilkelerine, araştırma ve yayın etiği kurallarına, dergi etik kurallarına uyulmuştur. Makale ile ilgili doğabilecek her türlü ihlallerde sorumluluk bana aittir. 


\section{KAYNAKÇA}

Acar, A. (2012). Türkiye'de Latin Alfabesine Geçiş Süreci ve Gazeteler. Iletişim Fakültesi Dergisi, 5-25.

Arı, A. (2002). Tevhid-i Tedrisat ve Laik Eğitim. Gazi Eğitim Fakültesi Dergisi, 181-192.

Arık, B. (2002). Karikatür Tarihimizde Önemli Bir Dönemeç: Marko Paşa Gazetesi. İstanbul Üniversitesi Iletişim Fakültesi Dergisi, 237-253.

Atatürk, K. (2009). Nutuk 1919-1927. (Z. Korkmaz, Dü.) Ankara: Atatürk Araştırma Merkezi.

Avcı, C. (2013). Harf İnkılabı ve Millet Mektepleri. Akdeniz insani Bilimler Dergisi, 43-60.

Baykara, T. (2011). Türk Inkılap Tarihi ve Atatürk Illkeleri. İstanbul: IQ Kültür Sanat Yayıncılık.

Berrak, A. (2012). Durum Çalışmasına Ayrıntılı Bir Bakış. Adnan Menderes Üniversitesi Eğitim Fakültesi Eğitim Bilimleri Dergisi, 1-9.

Büyüköztürk, Ş., Çakmak, E. K., Akgün, Ö. E., Karadeniz, Ş. \& Demirel, F. (2018). Bilimsel Araştırma Yöntemleri. Ankara: Pegem Akademi Yayınları.

Cantek, L., \& Gönenç, L. (2017). Muhalefet Defteri Türkiye'de Mizah Dergileri ve Karikatür. İstanbul: Yapı Kredi Yayınları.

Çepni, S. (2005). Araştırma ve Proje Çalışmalarına Giriş. Trabzon.

Çeviker, T. (2010). Karikatürkiye Karikatürlerle Cumhuriyet Tarihi 1923-2008. İstanbul : NTV Yayınları.

Çeviker, T. (2010). Karikatürkiye Karikatürlerle Cumhuriyet Tarihi 1923-2008. İstanbul: NTV.

Ertan, T. F., Aysal, N., Bakacak, A., Dinçer, H. \& Unat, K. (2018). Başlangııından Günümüze Türkiye Cumhuriyeti Tarihi. Ankara: Siyasal Kitabevi.

Gökçe, R. (1924, Mart 13). (133). Akbaba Dergisi.

Gökçe, R. (1926, Nisan 5). (348). Akbaba Dergisi.

Gökçe, R. (1928, Ağustos 30). (598). Akbaba Dergisi.

Gökçe, R. (1928, Eylül 17). (602). Akbaba Dergisi.

Gökçe, R. (1928, Ekim 29). (614). Akbaba Dergisi.

Gökçe, R. (1928, Ekim 22). (612). Akbaba Dergisi.

Gökçe, R. (1928, Kasım 1). (615). Akbaba Dergisi.

Gökçe, R. (1928, Kasım 29). (623). Akbaba Dergisi.

Görey, i. H. (1928, Kasım 4). (607). Akbaba Dergisi.

Günal, Z. (2008). Atatürk Ilkeleri ve Inkılap Tarihi (XVII.-XIX. Yüzyıl Islahat Hareketlerinden 1938'e. Ankara: Nobel Yayın Dağıtım.

Hünerli, S. (1993). Türkiye'de Gazete Karikatürünün Durumu ve Siyasi Karikatürün Söylemi. İstanbul: İstanbul Üniversitesi.

Hünerli, S. (1993). Türkiye'de Gazete Karikatürünün Durumu ve Siyasi Karikatürün Söylemi. İstanbul: İstanbul Üniversitesi. 
İnan, A. (2018). Türkiye Cumhuriyeti ve Türk Devrimi. Ankara: Türk Tarih Kurumu.

IRCICA. (2019, Mayıs 11). e-library. IRCICA: https://e-library.ircica.org/ adresinden alındı

Karataş, Z. (2015). Sosyal Bilimlerde Nitel Araştırma Yöntemleri. Manevi Temelli Sosyal Hizmet Araştırmaları Dergisi, 63-80.

Karikatür. (1924, Mart 13). (133). Akbaba Dergisi.

Karikatür. (1926, Nisan 5). (348). Akbaba Dergisi.

Karikatür. (1928, Kasım 12). (618). Akbaba Dergisi.

Karikatür. (1928, Ağustos 30). (598). Akbaba Dergisi.

Kaya, M. \& Acarlı, M. (2018). Cumhuriyet'in İlk Yıllarına Kadar Türkiye'de Karikatürün Tarihsel Gelişimi. Milli Kültü Araştırmaları Dergisi, 127-133.

Kaya, M. \& Acarlı, M. (2018). Cumhuriyet'in İlk Yıllarına Kadar Türkiye'de Karikatürün Tarihsel Gelişimi. Milli Kültür Araştırmaları Dergisi, 127-133.

Kayış, Y. (2004). Demokrat Parti Iktidarı Döneminde Siyasi Karikatür. İzmir: Dokuz Eylül Üniversitesi. Kayış, Y. (2004). Demokrat Parti İktidarı Döneminde Siyasi Karikatür. İzmir: Dokuz Eylül Üniversitesi. Kocatürk, U. (2000). Atatürk ve Türkiye Cumhuriyeti Tarihi Kronolojisi 1918-1938. Ankara: Türk Tarih Kurumu Basımevi.

Öğdü, H. (2011). Türk Siyasal Hayatının Karikatür Üzerinden Analizi: Akbaba Dergisi Örneği. Konya: Selçuk Üniversitesi.

Öngören, F. C. (1998). Cumhuriyetin 75. Yılında Türk Mizahı ve Hicvi. İstanbul: Türkiye İş Bankası Yayınları.

Sakin, S. (2011). Siyasi Karikatürlerde Emperyalizm Milletler Cemiyeti ve Türkiye. İstanbul: IQ Kültür Sanat Yayıncılık.

Subaşı, M. \& Okumuş, K. (2017). Bir Araştırma Yöntemi Olarak Durum Çalışması. Atatürk Üniversitesi Sosyal Bilimler Enstitüsü Dergisi, 419-426.

Tahir, R. (1924, Mart 6). (121). Zümrüdü Anka Dergisi.

Tahir, R. (1924, Mart 20). (120). Zümrüdü Anka Dergisi.

Tonga, N. (2008). Türk Edebiyatı Tarihinde Mühim Bir Mecmua: Akbaba (1922-1977). Turkish Studies Dergisi, 665-679.

Turan, E. T. (2018). Mustafa Kemal Paşa Ve Harf İnkılâbı. Vakanüvis - Uluslararası Tarih Araştırmaları Dergisi, 380-397.

Us, H. T. (2019, Nisan 27). Hakkı Tarık Us Dijital Koleksiyonu. Hakkı Tarık Us Dijital Koleksiyonu: http://www.tufs.ac.jp/common/fs/asw/tur/htu/adresinden alındı

Yetim, F. \& Akkoyunlu, S. B. (2017). Türk Modernleşmesine Erken Cumhuriyet Dönemi Basınında Karikatür Üzerinden Bir Bakış, , 3/3, (2017), 93. Tarih ve Gelecek Dergisi, 77-96. 
Yıldırım, A. \& Şimşek, H. (2005). Sosyal Bilimlerde Nitel Araştırma Yöntemleri. Ankara: Seçkin Yayınları.

Yılmaz, H. (2016). 1923 Yılı Mizah Basınında Kadınların Seçme-Seçilme Hakkı ve Kadınlar Halk Fırkası. Atatürk Üniversitesi Türk Inkılap Tarihi Enstitüsü Atatürk Yolu Dergisi, 263-296.

Yılmaz, N. F. (2017). 1923 Nüfus Mübadelesine Mizah Penceresinden Bakmak: Zümrüdü-anka. Uluslararası Tarih Araştırmaları Dergisi, 76-91.

Zengin, Z. S. (2002). Tevhid-i Tedrisat Kanunu'nun Hazırlanmasından Sonraki Illk Dönemde Uygulanışı ve Din Eğitimi. Dini Araştırmalar Dergisi, 81-106. 